\title{
Carbon Dioxide Electrochemical Reduction over Metal and Metal Free Nanostructures: Recent Progress and Future Perspective
}

\section{Fawad Ahmad*}

Hefei National Laboratory for Physical Sciences at the Microscale and Department of Chemical Physics University of Science and Technology of China Hefei, Anhui 230026, P. R. China

\begin{tabular}{|c|c|}
\hline ART I C LE INFO & A B S T R A C T \\
\hline Received: 8 May 2019 & \multirow{11}{*}{$\begin{array}{l}\text { Research in the area of electrocatalytic reduction of } \mathrm{CO}_{2} \text { to value-added } \\
\text { products has grown briskly in the past few decades. This is due to the } \\
\text { increasing amount of } \mathrm{CO}_{2} \text { in the atmosphere and a steady rise in global } \\
\text { fuel demand. Serious efforts are urgently needed to minimize to } \mathrm{CO}_{2} \\
\text { emission and enhance sources of global energy demand. } \\
\text { Electrochemical reduction (ECR) of } \mathrm{CO}_{2} \text { is considered to be the best } \\
\text { solution which not only reduces the increasing } \mathrm{CO}_{2} \text { accumulation but } \\
\text { also produces valuable fuels and chemicals. Sluggish kinetics, high over } \\
\text { potential, low selectivity, low durability and competitive side reactions } \\
\text { are the focal issues, to overcome these problems an efficient } \\
\text { electrocatalyst is needed. Here in this mini review we had tried to } \\
\text { discuss the fundamental factors that greatly influences catalytic activity } \\
\text { of the catalyst in the light of updated experimental and computational } \\
\text { data, which include size, crystal plane, grain boundary, metal metal- } \\
\text { oxide interface and finally a brief note on metal free catalyst and future } \\
\text { perspective of ECR of } \mathrm{CO}_{2} \text {. }\end{array}$} \\
\hline Revised: 27 May 2019 & \\
\hline Accepted: 05 July 2019 & \\
\hline Available online: 09 July 2019 & \\
\hline DOI: 10.33945/SAMI/AJCA.2020.1.8 & \\
\hline Electrochemical Reduction & \\
\hline Nanomaterial & \\
\hline Metal Free Catalyst & \\
\hline ECR CO2 & \\
\hline Metal Alloys & \\
\hline Value-Added Products & \\
\hline
\end{tabular}

GRA P H I C A L ABSTRACT

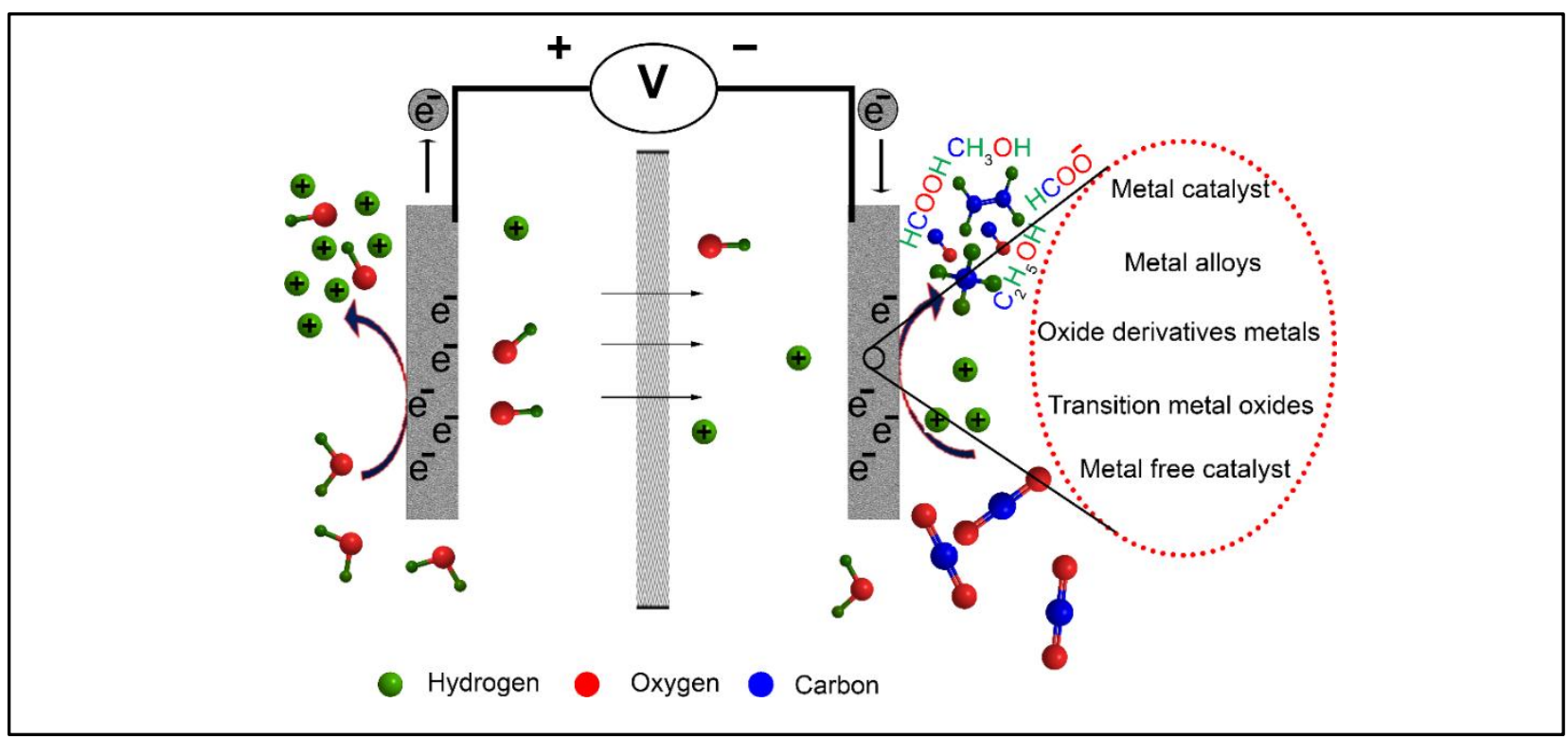

* Corresponding author's E-mail address: fawadics@gmail.com 


\section{The Review Scope}

This mini review article will open with a brief discussion of rising level of $\mathrm{CO}_{2}$ its causes and consequences, followed by the presentation of electrochemical reduction (ECR) of $\mathrm{CO}_{2}$, considered to be the best solution of the problem. Additionally we will summarize the fundamentals of ECR of $\mathrm{CO}_{2}$ and the parameters that greatly influences the catalytic ability of electrocatalyst. Finally, we will try to draw conclusions from the previous art dealing with the conversion of $\mathrm{CO}_{2}$ to $\mathrm{CO}, \mathrm{CH}_{4}, \mathrm{HCOH}$, etc., and recommend avenues of inquiry that researchers may wish to pursue in the future.

\section{Background}

Atmospheric $\mathrm{CO}_{2}$ concentrations increased briskly as Earth transitioned out of the last Ice Age, and the atmosphere has transformed vividly since the beginning of the Industrial Age with exclusively huge upsurges over the past few decades. The industrial age started in the mid-eighteenth century, the world population and energy consumption has surged vividly. The world demands another industrial revolution in which our sources of energy are accessible, affordable, and sustainable. Till to date fossil fuel energy covers approximately $86 \%$ of the world's core energy consumption [1]. The running down of fossil fuels lead to a series of serious problems [2-4]. Problems resulting from the utilization of fossil fuels are multi-faceted, but generally fall into two categories, economic-political and environmental issues. The illustrious and dubious hockey stick plots, which display how global average temperature has altered throughout history, illustrate the key effect that burning fossil fuels have on the environment [5]. Gases such as methane, $\mathrm{CO}_{2}$ etc., are liberated when fossil fuels are burned, these adsorb heat (infra-red radiation) from the Sun and halt its escape from the atmosphere. In the $2^{\text {nd }}$ half of the $20^{\text {th }}$ century, burning of fossil fuels has significantly increased the levels of these gases in the atmosphere, increased the planet's ability to contain heat and therefore increased global temperature [6].

The present concentration of $\mathrm{CO}_{2}$ in the atmosphere, which hit $400 \mathrm{ppm}$ in 2014, is above than any level recorded during the 800,000 years examined, which veered between $\sim 200 \mathrm{ppm}$ and $\sim 300 \mathrm{ppm}$ [7]. Geochemical evidences show that the last time $\mathrm{CO}_{2}$ concentration equaled the present levels recorded over two hundred thousand years ago [8]. Some of the environmental effects of the current sudden hasty change are as follows; increasing acidity of ocean [9], boosting periodically risky weather events [10], loss of polar ice [11], decreasing yield of crops [12], sinking concentration of ocean oxygen [13], rising sea levels [14], and increasing rate of extinction [15]. Each of these also have a profusion of knock-on effects, too many to list. Therefore, mitigating the effects produced by the high $\mathrm{CO}_{2}$ discharge has turn into a demanding concern to the present-day society $[16,17]$. To solve the previously mentioned problems, a large number of studies have concentrated on energy- and environmental-allied topics [18-20]. During the previous 3-4 decades, traditional fossil fuels have been partially swapped by clean and sustainable energy sources (i.e., solar, wind, and tide) to alleviate $\mathrm{CO}_{2}$ discharge [21]. Renewable energy sources, such as wind, tide and solar are enticing substitutes to fossil energy, because they are carbon dioxide neutral and, therefore, do not fluctuate the greenhouse influence. However, these sorts of sustainable energy are not accessible on requirement because of their ephemeral character. Moreover, these renewable energy sources are geographical, seasonal, and intermittent. As 
a result, the complete usage of renewable energy is usually apprehensive with energy storage as well as conversion technologies.

One choice is to stock this energy as a liquid fuel that has high energy density (HED) and can be conveniently transported on demand, for instance $\mathrm{CH}_{3} \mathrm{OH}$. This powerto-fuel (PF) cycle can be attained indirectly, via electrolysis and thermocatalytic transformation, or directly by ECR. In the first approach, renewable energy is applied to split water into $\mathrm{H}_{2}$ and $\mathrm{O}_{2}$ as a lucrative byproduct. The $\mathrm{H}_{2}$ is then subjected to react with $\mathrm{CO}_{2}$, e.g., through the water gas shift (WGS) reaction to spawn syngas, which can be consecutively converted into a number of valuable products. Thus, instead of being an unwanted waste, potentially ruining the planet, $\mathrm{CO}_{2}$ may become a profitable and low-cost carbon feedstock that also substitutes fossil fuels in this role [22-24].

An alternative alley adjoins $\mathrm{H}_{2} \mathrm{O}$ electrolysis with $\mathrm{CO}_{2}$ hydrogenation in an electrochemical cell (ECC) supplied with water and carbon dioxide to generate $\mathrm{HCOOH}$ and $\mathrm{CH}_{3} \mathrm{OH}$. Such technology, if effectuated on industrial level, would reuse the discharged carbon dioxide into valueadded products, definitely balancing the over-all carbon cycle. It is also viable to convert $\mathrm{CO}_{2}$ into $\mathrm{CO}$ in an EC container, therefore generating syngas. Research achievements on the ECR of $\mathrm{CO}_{2}$ have expanded hastily during the previous decades and the potential ability is colossal. Nevertheless, the challenges are considerable. Firstly, $\mathrm{CO}_{2}$ is a nonreactive molecule, not easy to go through chemical reaction. Triggering the $\mathrm{CO}_{2}$ by reduction entails not just a momentous energy supply but also extremely active electrocatalysts [25]. Secondly, $\mathrm{CO}_{2}$ solubility in aqueous environs needed for ECR is comparatively low. These restrictions stance major challenges linked to electrochemical catalysis, EC cell engineering \& electrochemistry.
For instance, $\mathrm{CH}_{3} \mathrm{OH}$ formation is described by the following reactions [26].

Cathodic Rxn

$$
\begin{aligned}
& \mathrm{CO}_{2}(a q)+6 \mathrm{H}^{+}+6 \mathrm{e}^{-} \rightarrow \mathrm{CH}_{3} \mathrm{OH}+\mathrm{H}_{2} \mathrm{O} \\
& \mathrm{E}^{\mathrm{o}}=-0.22 \mathrm{~V}
\end{aligned}
$$

Anodic Rxn

$$
\begin{aligned}
& 3 \mathrm{H}_{2} \mathrm{O} \rightarrow 1.5 \mathrm{O}_{2}+6 \mathrm{H}^{+}+6 \mathrm{e}^{-} \\
& \mathrm{E}^{\circ}=+0.99 \mathrm{~V}
\end{aligned}
$$

\section{Overall Rxn}

$\mathrm{CO}_{2}(a q)+2 \mathrm{H}_{2} \mathrm{O} \rightarrow \mathrm{CH}_{3} \mathrm{OH}+1.5 \mathrm{O}_{2}$

$\mathrm{E}^{\mathrm{o}}=+1.21 \mathrm{~V}$

The fundamentals of the ECR of $\mathrm{CO}_{2}$ is explained below. In addition, the basic challenges are also addressed. For extra meticulous information, the readers are directed to some superb review articles [2634]. In the ECR of $\mathrm{CO}_{2}$, electrical energy is provided to ECC having an aqueous electrolytic solution saturated with $\mathrm{CO}_{2}$ by bubbling. The reduction of $\mathrm{CO}_{2}$ take place on the surface of cathode and it is electrically evened by the electrolytic fragmentation of $\mathrm{H}_{2} \mathrm{O}$ on the surface of anode providing the $\mathrm{H}^{+}$required to hydrogenate $\mathrm{CO}_{2}$ via an ion exchange membrane (IEM), as it is schematically showed in Figure 1 . The oxidation and reduction occurring on the anode and cathode respectively.

To expedite the reaction kinetics, a catalyst is usually decorated on the surface of electrode. Henceforward, we concentrate on the cathode side, which is the limiting factor in the ECC performance. $\mathrm{CO}_{2}$ can be constantly supplied to the ECC via bubbling in the solution. Yet, the restricted solubility of $\mathrm{CO}_{2}$ stances a momentous task. Typically, the ECR of $\mathrm{CO}_{2}$ is performed in $\mathrm{pH} \sim 7$ or slightly basic media because such condition eases the production of the $\mathrm{HCOO}^{-}$, which is an intermediate in the $\mathrm{CO}_{2}$ hydrogenation alley. In strong basic solutions, above $\mathrm{pH}=$ 
9, the production of the $\mathrm{HCO}_{2}^{-}$and $\mathrm{CO}_{3}^{2-}$ ion will be expedited, restricting the contribution of carbon dioxide in the reduction reaction alleys. Dropping the $\mathrm{pH}$ allows for dissolving more carbon dioxide to carbonic acid.

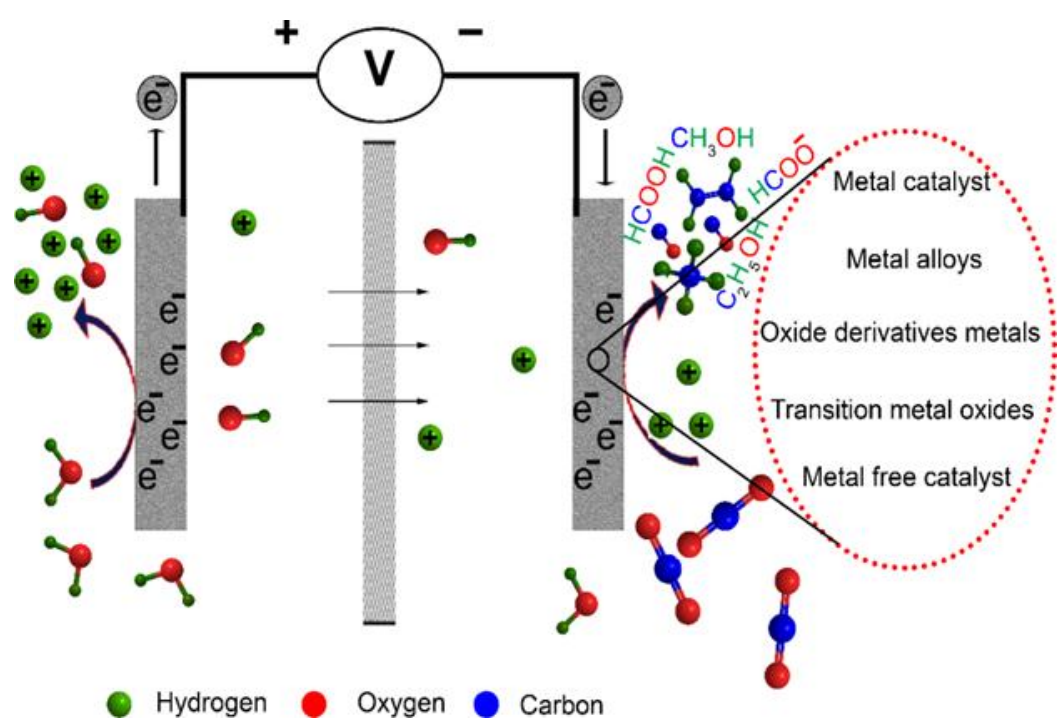

Figure 1. Schematic representation of reaction unit \& different class of the electrocatalysts used for ECR of $\mathrm{CO}_{2}$

However, acidic media facilitate the HER, while impeding the generation of the $\mathrm{HCOO}^{-}$. Optimal $\mathrm{pH}$ of the media for the ECR of $\mathrm{CO}_{2}$ is still controversial among scientists.

Though the ECR of $\mathrm{CO}_{2}$ is thermodynamically feasible, the reduction potential of $\mathrm{CO}_{2}$ is comparable to that of $\mathrm{H}_{2} \mathrm{O}$ reduction. Consequently, there is always strain between the $\mathrm{CO}_{2}$ reduction and the more thermodynamically feasible HER (potentials are displayed versus SHE, at 25 ${ }^{\circ} \mathrm{C}$ and $\mathrm{pH}=14$ ):

$\mathrm{CO}_{2}(\mathrm{aq})+\mathrm{H}_{2} \mathrm{O}+2 \mathrm{e}^{-} \rightarrow \mathrm{HCOO}^{-}+\mathrm{OH}^{-}$

$\mathrm{E}^{\circ}=-1.02 \mathrm{~V}$

$2 \mathrm{H}_{2} \mathrm{O}+2 \mathrm{e}^{-} \rightarrow \mathrm{H}_{2}+2 \mathrm{OH}^{-}$

$\mathrm{E}^{\mathrm{O}}=-0.83 \mathrm{~V}$

Consequently, the energy provided to ECC will be absorbed by two contending reduction mechanisms: HER via $\mathrm{H}_{2} \mathrm{O}$ electrolysis and $\mathrm{CO}_{2}$ reduction into desired products, e.g., $\mathrm{CH}_{3} \mathrm{OH}$ or $\mathrm{HCOOH}$. High selectivity and high yielding rates of the converted product can only be attained if the catalyst restrains HER so that maximum supplied electricity will be used in the $\mathrm{CO}_{2}$ reduction.

In addition to the $\mathrm{H}_{2} \mathrm{O}$ splitting, there are many other competing reactions occurring during the ECR of $\mathrm{CO}_{2}$. Possible reaction alleys, including the $\mathrm{CH}_{3} \mathrm{OH}, \mathrm{HCOOH}$ and $\mathrm{HCOH}$ yielding, are given along with corresponding reduction potentials $\left(\mathrm{E}^{\circ}\right)$ (given versus $\mathrm{NHE}$, at $25^{\circ} \mathrm{C}$ and $\mathrm{pH}=7$ ):

$$
\begin{aligned}
& \mathrm{CO}_{2}+8 \mathrm{H}^{+}+8 \mathrm{e}^{-} \rightarrow \mathrm{CH}_{4}+2 \mathrm{H}_{2} \mathrm{O}, \\
& \mathrm{E}^{\circ}=-0.24 \mathrm{~V} \\
& \mathrm{CO}_{2}+6 \mathrm{H}^{+}+6 \mathrm{e}^{-} \rightarrow \mathrm{CH}_{3} \mathrm{OH}+\mathrm{H}_{2} \mathrm{O}, \\
& \mathrm{E}^{\mathrm{o}}=-0.38 \mathrm{~V}
\end{aligned}
$$

$\mathrm{E}^{\mathrm{o}}=-0.51 \mathrm{~V}$

$\mathrm{CO}_{2}+2 \mathrm{H}^{+}+2 \mathrm{e}^{-} \rightarrow \mathrm{CO}+\mathrm{H}_{2} \mathrm{O}$,

$\mathrm{E}^{\mathrm{o}}=-0.52 \mathrm{~V}$

$\mathrm{CO}_{2}+2 \mathrm{H}^{+}+2 \mathrm{e}^{-} \rightarrow \mathrm{HCOOH}$,

$\mathrm{E}^{\mathrm{o}}=-0.61 \mathrm{~V}$ 
$\mathrm{CO}_{2}+\mathrm{e}^{-} \rightarrow \mathrm{CO}_{2}^{--}, \mathrm{E}^{\mathrm{o}}=-1.9 \mathrm{~V}$

Regarding the products, some of the reactions given above are entitled as "parasitic reactions". These loathsome reactions absorb the energy (current) given to the ECC, minimizing the quantity of the energy absorbed in the preferred reaction pathway. It's worthy to mention that the uni-electronic reaction of $\mathrm{CO}_{2}$ is less promising than the $\mathrm{H}^{+}$-tied multi-electronic alleys, which is basically lucrative for the ECR of $\mathrm{CO}_{2}$ into fuels and value-added chemicals. The alleys presented in R- 6 - R11 are the inclusive reactions. Each of these reaction has many simple phases and several possible reaction mechanisms.

$$
\left\{\begin{array}{c}
\mathrm{CO}_{2}(a q)+\mathrm{H}^{+}+\mathrm{e}^{-} \rightarrow \mathrm{HOCO}^{-} \\
\mathrm{HOCO}^{-}+\mathrm{H}^{+}+\mathrm{e}^{-} \rightarrow \mathrm{H}_{2} \mathrm{O}+\mathrm{CO} \\
\mathrm{CO}+\mathrm{H}^{+}+\mathrm{e}^{-} \rightarrow \mathrm{HCO} \\
\mathrm{HCO}+\mathrm{H}^{+}+\mathrm{e}^{-} \rightarrow \mathrm{HCHO} \\
\mathrm{HCHO}+2 \mathrm{H}^{+}+2 \mathrm{e}^{-} \rightarrow \mathrm{CH}_{3} \mathrm{OH}
\end{array}\right\}
$$

Reaction Mechanism (I)

$$
\left\{\begin{array}{c}
\mathrm{CO}_{2}(a q)+\mathrm{H}^{+}+\mathrm{e}^{-} \rightarrow \mathrm{HOCO}^{-} \\
\mathrm{HOCO}^{-}+\mathrm{H}^{+}+\mathrm{e}^{-} \rightarrow \mathrm{HCOOH} \\
\mathrm{HCOOH}+\mathrm{H}^{+}+\mathrm{e}^{-} \rightarrow \mathrm{HCO}+\mathrm{H}_{2} \mathrm{O} \\
\mathrm{HCO}+\mathrm{H}^{+}+\mathrm{e}^{-} \rightarrow \mathrm{HCHO} \\
\mathrm{HCHO}+2 \mathrm{H}^{+}+2 \mathrm{e}^{-} \rightarrow \mathrm{CH}_{3} \mathrm{OH}
\end{array}\right\}
$$

Reaction Mechanism (II)

For example, in the ECR of $\mathrm{CO}_{2}$ into $\mathrm{CH}_{3} \mathrm{OH}$ there are minimum two imaginable reactions alleys. One mechanism contains $\mathrm{CO}$ and $\mathrm{HOCO}^{-}$as an intermediates, RM (I). The second possible mechanism continues through the generation $\mathrm{HCOO}^{-}$and $\mathrm{HCOOH}$, RM (II). Both reaction mechanisms contains the generation of $\mathrm{HCO}$ and HCHO: [26]

In addition to the thermodynamic considerations, there are also kinetic barriers. Broadly speaking, it is more challenging to transform $\mathrm{CO}_{2}$ into greatly enticing hydrocarbons such as $\mathrm{HCOOH}$, $\mathrm{C}_{2} \mathrm{H}_{5} \mathrm{OH}$ and $\mathrm{CH}_{3} \mathrm{OH}$ than into small molecules i.e., CO. Production of $\mathrm{C}_{2}-\mathrm{C}_{3}$ species needs multiple $\mathrm{H}^{+}$-tied electron transfers, which fallouts in notable kinetic obstacles and, as a result, low faradic efficiency. Searching an appropriate electrocatalyst that can enhance generation of all the reaction intermediates concurrently, while suppressing loathsome parasitic reaction is a big task. One of the fundamental challenge in the ECR of $\mathrm{CO}_{2}$ is the high over potential. The over potential comprises of three elements, namely activation over potential, ohmic over potential and concentration over potential. The ohmic losses are as a result of electrode and electrolyte resistances. The kinetic obstacle is represented by activation over potential, i.e., the energy needed to keep the reaction at a momentous extent. Electrocatalyst may loss its activity due to poisoning triggered by sorption of intermediates. Therefore, selection of an appropriate material for electrode surface is a tedious job. The concentration over potential establishes because of the mass transfer restrictions produced by the transmission of products and reactants to/from the electrocatalyst surface. Since the ECR of $\mathrm{CO}_{2}$ is performed in an aqueous solution at ambient temperatures, the diffusion is pretty low. If the flow rate of carbon dioxide to the electrocatalyst surface is considerably sluggish than the utmost rate of its utilization at the electrocatalyst surface, a limiting current is attained. Thus, the electrocatalyst surface morphology turn out to be a key feature in the ECC performance. For any applied operation, the matter of the limited mass transfer of $\mathrm{CO}_{2}$ to the electrocatalyst surface has to be properly addressed.

\section{Recent Progress on Carbon Dioxide Electrochemical Reduction over Metal nanocrystals}

The research field of ECR of $\mathrm{CO}_{2}$ has been 
extensively studied since the cutting-edge work by Hori et al., in the 1980s [35,36]. Tremendous efforts has been made to achieve low-cost and easily synthesizable, numerous types of metals and alloys for ECR of $\mathrm{CO}_{2}$ [37-47]. Scientists have thoroughly investigated the ECR of $\mathrm{CO}_{2}$ on $\mathrm{Zn}$ [48], $\mathrm{Sn}$, $\mathrm{Au}[49,50], \mathrm{Ag}[51,52], \mathrm{Cu}$ [53-61], $\mathrm{Pd}, \mathrm{Cu}-\mathrm{Au}$ [62], $\mathrm{Ni}$ etc. metal electrodes. These materials can catalyze $\mathrm{CO}_{2}$ reduction because of their d-electron availability [63] and low surface $\mathrm{CO}_{2}$ sorption strengths [64]. Actually, $\mathrm{CO}_{2}^{--}$formation has considered as a rate-determining step for carbon dioxide reduction in maximum cases. Therefore, the key task of these electrocatalysts is to stabilize the reaction intermediate to achieve high faradic efficiency for $\mathrm{CO}_{2}$ reduction. Depending on penchant to tie various reaction intermediates and ultimate products, metal electrodes can be divided into three groups [46-65]. Such as given in Figure 1, group I contains $\mathrm{Hg}$, Sn, In, and $\mathrm{Pb}$, etc., producing $\mathrm{HCOO}^{-}$or $\mathrm{HCOOH}$ as the key products. Metals of this group can rarely bind the $\mathrm{CO}_{2}^{--}$, therefore $\mathrm{HCOO}^{-}$or $\mathrm{HCOOH}$ is produced via an outer-sphere mechanism.

$\mathrm{Ag}, \mathrm{Pd}, \mathrm{Zn}$, and $\mathrm{Au}$ are the members of group II, which have the ability to bind ${ }^{*} \mathrm{COOH}$ firmly for further reaction. Though, the ${ }^{*} \mathrm{CO}$ is softly attached to the surface of the metal. Consequently, it desorbs easily from the surface of the electrocatalyst and arises as a major product. Group III contain only $\mathrm{Cu}$, it having the ability to bind ${ }^{*} \mathrm{CO}$ and convert * $\mathrm{CO}$ to hydrocarbons and alcohols via ${ }^{*} \mathrm{CHO}$ or ${ }^{*} \mathrm{COH}$ reaction intermediates.

Generally, the main yielded compounds spawned by the above discussed three groups are formate ion/formic acid, CO, and hydrocarbons, respectively. As mentioned above, a competing reaction, HER, should not be out of mind in the case of ECR of $\mathrm{CO}_{2}$ in aqueous solutions. As * $\mathrm{CO}$ intermediate is attached firmly enough to shun further reduction of carbon dioxide, the $\mathrm{H}_{2}$ particularly releases on surface of metals like $\mathrm{Fe}, \mathrm{Ni}, \mathrm{Ti}$, and $\mathrm{Pt}$. Thus, regulating the binding energies of pivotal intermediates is censorious for ultimate product selectivity and energy efficiency of $\mathrm{CO}_{2}$ ECR. According to Paul Sabatier principle, the outstanding catalysts should have proper interactions between intermediates and electrocatalysts surfaces [66,67]. Literally, the bona fide surface chemistry of TM based electrocatalyst is even more intricate than the previously mentioned theories [68-70]. Kuhl et al., used seven transition metals for ECR of $\mathrm{CO}_{2}$ [71]. Amazingly, both methanol and methane were generated on $\mathrm{Pt}, \mathrm{Ni}, \mathrm{Cu}$, $\mathrm{Zn}$, and Ag metals. For the time being, only methanol was spawned on $\mathrm{Au}$, and methane was formed on Fe. The oxophilicities difference of $\mathrm{Au}$ and $\mathrm{Fe}$ led to such kind of results, it may explained as the strong oxophilic centers ( $\mathrm{Fe}$ ) will break $\mathrm{C}-\mathrm{O}$ bond of $\mathrm{CO}_{2}$ producing $\mathrm{CH}_{4}$ while less oxophilic centers $(\mathrm{Au})$ hug $\mathrm{C}-\mathrm{O}$ from the back side and yielding $\mathrm{CH}_{3} \mathrm{OH}$. Therefore, it sounds practical to get preferred products (hydrocarbon or alcohol) by tuning the binding clout of $\mathrm{O}_{\text {ads }}$.

The ECR of $\mathrm{CO}_{2}$ on bulk materials was thoroughly studied and reviewed by Hori et al.[37]. Recently nanotechnology manipulated almost every field of material science, researchers are engineering the surfaces of the catalytic material focusing on the active sites to enhance its electrocatalytic activity. As discussed earlier that $\mathrm{Au}$ have superior activity for ECR of $\mathrm{CO}_{2}$ at moderate overpotential that's why different research groups have synthesized its different geometric forms such as nanowires [72], films [73], and particles [50,74,75]. Huan et al. anchored $\mathrm{Au}$ NPs on the carbon nanotubes (CNTs) and tested ECR of $\mathrm{CO}_{2}$ in $0.5 \mathrm{M} \mathrm{NaHCO}_{3}$, he observed remarkable performance with a current density of 10 $\mathrm{mA} \mathrm{cm}{ }^{-2}$. The high capital cost of the $\mathrm{Au}$ is preventing its implementation on industrial 
scale. The nearest and best suitable substituent of the $\mathrm{Au}$ is $\mathrm{Ag}$ which is cheaper and shows high selectivity for ECR of $\mathrm{CO}_{2}$ to CO [76-79].

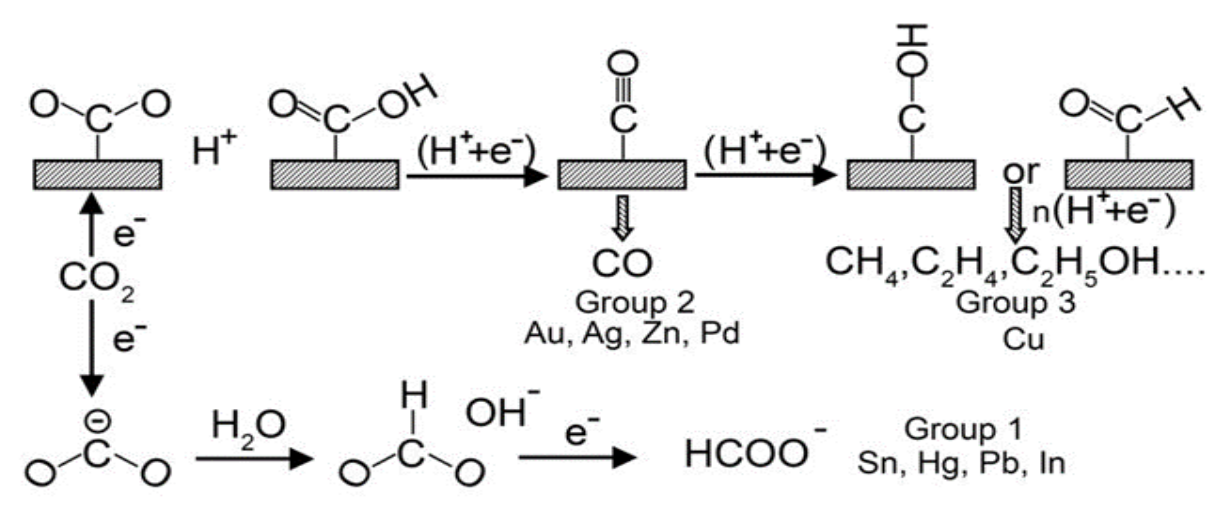

Figure 2. ECR of $\mathrm{CO}_{2}$, reaction mechanism and products [41]. (Reproduced with permission from ref 41. Copyright 2016, Wiley-VCH.)

\section{Size Effect}

Activity as a function of grain size is an evergreen and amazingly interesting debatable area among nano-chemist and nanotechnologist. Several systematic studies are reported in the literature regarding size effect. One of the recent review published by Li et al., [80] although the review is not about ECR of $\mathrm{CO}_{2}$ but still full of amusement for all nano-chemist. The author argued that downsizing below certain limit $(2 \mathrm{~nm})$ led to a great degree of thermodynamic destabilization which was also supported by De Jong et al., theoretical studies [81].

Sun et al. had thoroughly studied ECR of $\mathrm{CO}_{2}$ on different sizes of $\mathrm{Au}$ nanoparticles such as 4, 6, 8 and $10 \mathrm{~nm}$. Figure 3-a. illustrates that they had assumed Au NPs as ideal cuboctahedra and then obtained relationship between size and active site density from DFT calculation. The $2.7 \mathrm{~nm}$ NPs having ratio of active surface atoms to bulk atom $\sim 1$ signifying their high activities. NPs with smaller size than $2.7 \mathrm{~nm}$ has significant size effect [82-84]. Figure 3b shows that particles with an average size of $8 \mathrm{~nm}$ have mass activity $3 \mathrm{~A} / \mathrm{g}$ and the highest faradic efficiency i.e., $97 \%$ at $-0.52 \mathrm{~V}$ vs RHE. DFT calculation probes to the mechanism. Concluding that edges have active sites resposible for $\mathrm{CO}$ generation $[52,85,86]$, while the corner are responsible for the $\mathrm{H}_{2}$ production. Consequently there is always strain between $\mathrm{CO}$ and $\mathrm{H}_{2}$ evolution. As the size increase from $4 \mathrm{~nm}$ to $8 \mathrm{~nm}$ the edges are more exposed resulting high selectivity for CO. Similarly smaller size $\mathrm{Au}$ NPs have high density of corners which has high potential of strong binding and results $\mathrm{H}_{2}$ generation [75]. Contrary to the Sun et al. Bao et al., had observed different results for ECR of $\mathrm{CO}_{2}$ on Pd electrocatalyst. They used 2.4, 3.7, 4.5, 6.2, 7.8 and $10.3 \mathrm{~nm}$ NPs and recorded $\mathrm{CO}$ generation $\mathrm{FE}>91 \%$ for 10.3 $\mathrm{nm}$ at $-0.89 \mathrm{~V}$ vs RHE with $>18$-fold high current density compared to $3.7 \mathrm{~nm}$ NPs. The author explained on the basis of theoretically calculated thermodynamic parameters that the corner and edges having more favorable active sites for $\mathrm{CO}_{2}$ adsorption and reaction intermediate $\left(\mathrm{COOH}^{*}\right)$ formation while $\mathrm{H}^{*}$ for HER may produce equally at any three sites [86]. Strasser et al. had used Cu NPs ranging 2 $15 \mathrm{~nm}$ for ECR of $\mathrm{CO}_{2}$, a drastic increase in FE coupled with high selective $\mathrm{CO}$ and $\mathrm{H}_{2}$ 
production and decrease in HCs selectivity was observed with the decrease in the size of the $\mathrm{Cu}$ NPs. It's worth to mention, that HCs formation disappeared significantly below 3 $\mathrm{nm}$ range [87]. Masel et al. reported that 5 nm Ag NPs having 10 times higher ECR of $\mathrm{CO}_{2}$ than bulk while further below $5 \mathrm{~nm}$ the activity decreases which maybe be due to the binding energy of the intermediate [78].
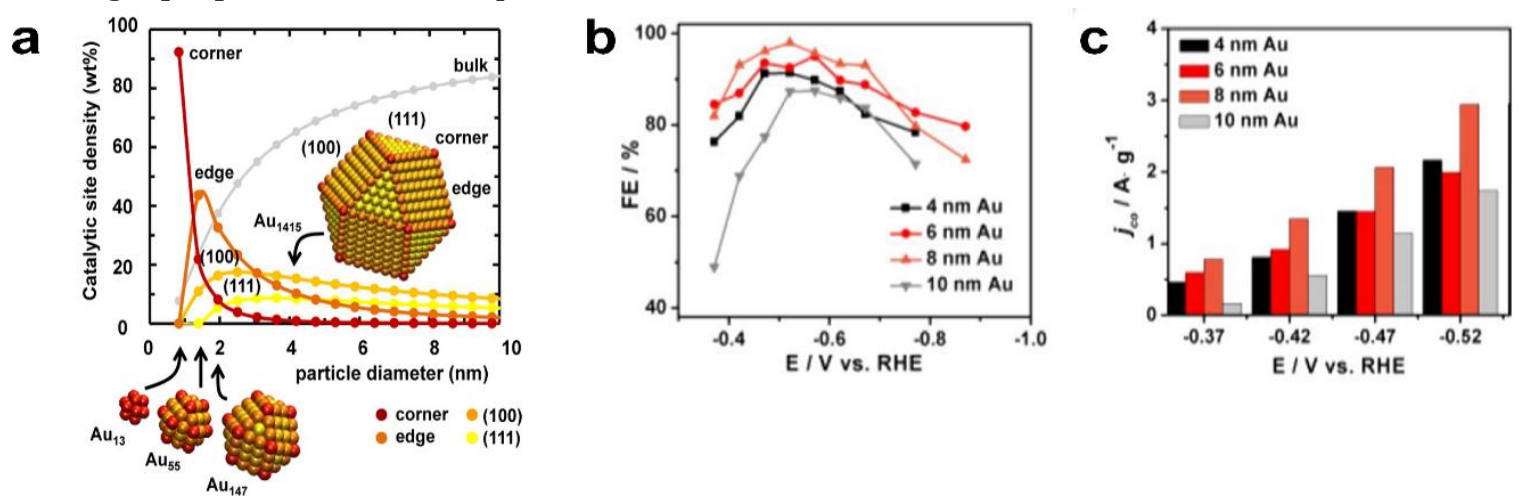

Figure 3. (a) Density of adsorption sites on closed-shell cuboctahedral Au clusters vs the cluster diameter. The weight fraction of Au bulk atoms is marked with gray dots (b) FEs and (c) mass activities [75]. (Reproduced with permission from ref 75. Copyright $2013 \mathrm{~J}$. Am. Chem. Soc.)

\section{Crystal planes effect}

Catalysis is highly influenced by adsorption, and the fundamental of surface chemistry clearly explains that adsorption is a function of active sites on the surface of the adsorbent. Most of the synthetic material have uniform bulk structure but rarely have regular surface. Actually the surface is a combination of different arrangements of steps, defects and smooth regions. This variation in surface atomic arrangement led to various electronic properties [88]. This local variation in atomic arrangement ultimately results variation in catalytic activities. Some where it exhibit ideal behavior specifically in case of electrochemical catalysis while at some stages it shows high degree of deviations. Few systematic studies clearly explain the planes effect and explains that edge and corner are shape dependent, its ratio varies as the shape changes [75-85]. Luo et al., recently reported shape dependent ECR of $\mathrm{CO}_{2}$ on triangular Ag NPs. They prepared triangular nanoplates and NPs of similar size and observed that triangular nanoplates have significant improved performance such as FE
96.8\%, energy efficiency $61.7 \%$ and convincing durability of 7 days. In addition to this they observed $\mathrm{CO}$ at extremely low overpotential $(96 \mathrm{mV}$ ). This reconciliate its robust shape dependent activity in comparison to previously reported data [52, 85-89]. Computational study help to probe into the reactivity of the $\mathrm{Au}$ on various facets via established hydrogen model $[75,85,86]$. Figure 4 -a is the diagrammatically represents Gibbs free energy $(\Delta \mathrm{G})$ for ECR of $\mathrm{CO}_{2}$ on (110), (111), (100) and Ag55 cluster, where the total sum of $\Delta G$ values needed for the suggested four steps reaction was simulated and calculated (Figure 4-c). The barrier is the formation of $\mathrm{COOH}^{*}$ which is proton-coupled electron-transfer step, every facet of catalyst have to cross this barrier. The $\Delta \mathrm{G}$ of formation of $\mathrm{COOH}^{*}$ on (100) facet is lower than on (111) facets which proves the favorability of (100) facet for ECR of $\mathrm{CO}_{2}$. Moreover the difference in $\Delta \mathrm{G}$ of formation on (100) and (110) is almost negligible. It's worth to mention that, triangular Ag nanoplates have (100) dominating facet while the same size Ag NPs don't have the same phenomenon. From thermodynamics perspective the $2^{\text {nd }} \mathrm{H}^{+}$ 
coupled e- transfer step is more feasible after the first free energy step for adsorbed CO*. Interestingly it's same on all facets. Comparatively $\mathrm{COOH}^{*}$ formation is more feasible on Ag55 cluster but due to its overbinding with $\mathrm{CO}^{*}$ give low yielding. Concluding that triangular plates have dominance of (100) facets and also easily evolve CO consequently overpotential is drop down as well as onset potential. Previous studies explained the fact that edge-to-corner ratio is very important for the high activity and selectivity of electrochemical reduction of carbon dioxide. Edge-to-corner as function of cluster diameter is illustrated in Figure 4-b, which indicates that triangular Au nanoplates maintain a high edge-to-corner ratio in the range of 2-12 $\mathrm{nm}$. This conforms the availability of more active sites which in turn make it a super catalyst for ECR of $\mathrm{CO}_{2}$ [90]. Woo et al. studied the effect of different facets of $\mathrm{Zn}$ for ECR of $\mathrm{CO}_{2}$. He explained that in hierarchical hexagonal $\mathrm{Zn}$ the favorable facet for CO generation is (101) while for HER (002). The (101) bear high activity and selectivity for CO which may be due to stabilization effect of $\mathrm{COOH}^{*}$. This strongly recommend that tuning the ratio of $(101) /(002)$ play a vital role in engineering catalyst of desired selectivity and activity for ECR of $\mathrm{CO}_{2}$ [91]. Sun et al., successfully synthesized $\mathrm{Au}$ NWs with $2 \mathrm{~nm}$ width and applied for ECR of $\mathrm{CO}_{2}$, their findings also based on the same explanation that the high activity ( 1.84 A/g), FE (94\%) and 6 hour durability without alteration in its significance is due to high edge-to-corner ratio which is supported by DFT calculation [72]. Yousung et al., further explained that edges and corner are dependent on local coordination environment. The planes as well as dihedral angle which constitutes the planes are key factors for tuning the activity of the catalyst [92].

\section{Oxide-Derived metal catalysts}

Recently, Oxide-derived (OD) metal electrocatalysts have gained exceptional interest because to their conspicuous robust activity for ECR of $\mathrm{CO}_{2}$ [50, 61, 93-101]. Kanan and Chen compared pure Sn to composite of $\mathrm{Sn} / \mathrm{SnOx}$ and recorded tremendous increase in the $\mathrm{FE}$ and current density for ECR of $\mathrm{CO}_{2}$ [97]. Contrary to this FE of Sno was less than $1 \%$. What's happening on the surface of the composite is much debatable but it seems that the composite surface stabilize the reaction intermediate $\mathrm{CO}_{2}^{\circ-}$ which may a key factor for high activity. Baruch et al. thoroughly studied in situ ATR-IR of ECR of $\mathrm{CO}_{2}$ on $\mathrm{Sn}$ surface. The ATR-IR intense peaks represents the generation of surface-bound Sn-carbonates.
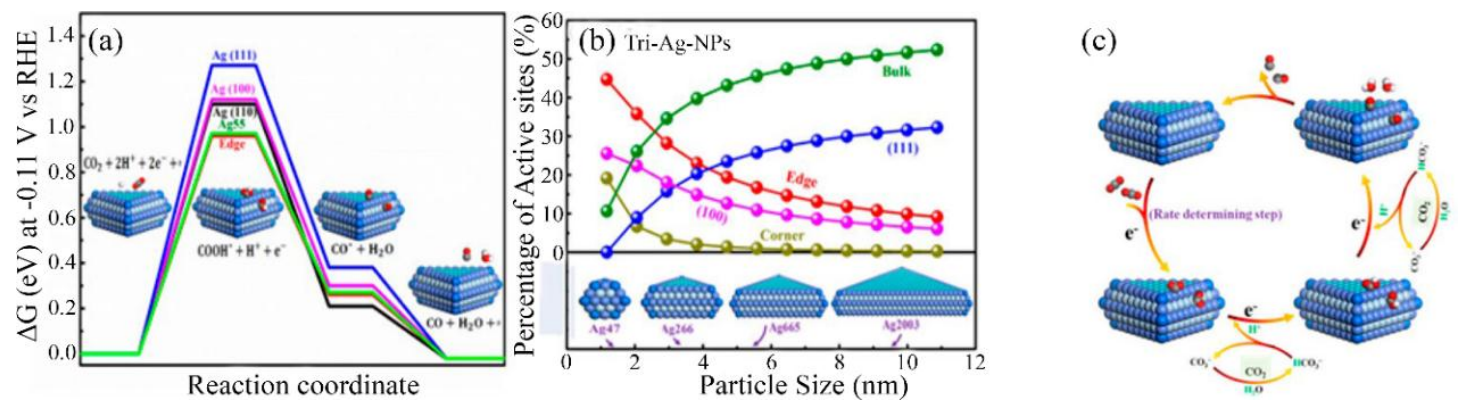

Figure 4. (a) Free energy diagrams for ECR of $\mathrm{CO}_{2}$ to $\mathrm{CO}$ on different facets and Ag 55 cluster at $-0.11 \mathrm{~V}$; active adsorption site density on (b) Tri-Ag-NPs and(c) proposed mechanism for ECR of $\mathrm{CO}_{2}$ to $\mathrm{CO}$ on Tri-Ag-NPs [90]. (Reproduced with permission from ref 90. Copyright 2017 J. Am. Chem. Soc.) 
What's happening on the surface of the composite is much debatable but it seems that the composite surface stabilize the reaction intermediate $\mathrm{CO}_{2}^{--}$which may a key factor for high activity. Baruch et al., thoroughly studied in situ ATR-IR of ECR of $\mathrm{CO}_{2}$ on Sn surface. The ATR-IR intense peaks represents the generation of surface-bound Sn-carbonates. Since $\mathrm{Sn}_{6} \mathrm{O}_{4}(\mathrm{OH})_{4}$ NPs yield more $\mathrm{HCOO}^{-}$than $\mathrm{SnO}_{2}$ NPs at a lessnegative potential, $\mathrm{Sn}^{2+}$ was suggested to be more favorable and having more active sites for ECR of $\mathrm{CO}_{2}$. On this basis the authors argue that first $\mathrm{SnO}_{2}$ converts to $\mathrm{Sn}^{2+}$ and then approaches to $\mathrm{CO}_{2}$ yielding surfaceattached carbonates which finally gives formate. It's important to note that in this scenario the surface-attached carbonates are considered as reaction intermediates. These points clearly elaborates the participation of SnOx in Sn-SnOx complex surface for ECR of $\mathrm{CO}_{2}$. Researchers have used this mesmerizing approach and applied it for a number of metals and got extraordinary results. Hori thoroughly studied Pd by using a variety of electrode structure, different electrolytes and electrochemical cell [37]. Its well documented that $\mathrm{Pd}$ basically produces $\mathrm{HCO}_{2}^{-}$and $\mathrm{H}_{2}$ in $\mathrm{HCO}_{3}^{-}$aqueous solution saturated with $\mathrm{CO}_{2}$. Wrighton investigated that the equilibrium potential for $\mathrm{CO}_{2} / \mathrm{HCO}_{2}^{-}$ in the said condition vs RHE is $\sim 0 \mathrm{~V}$ [102]. The $\mathrm{PbO}$ electrode can be prepared by acid anodization [103], the formation of $\mathrm{Pb}^{2+}$ is confirmed by XPS analysis given in Figure 5 c. EC analysis showed that the $\mathrm{H}_{2}$ production was significantly decreased in a full spectra of $\mathrm{pH}$ range such as acidic, neutral and basic media given in Figure 5 -f, $g$ \& $\mathrm{h}$. At the same time $\mathrm{HCO}_{2}^{-}$generation was tremendously increased which is given as $\mathrm{FE}$ and Tafel slope in the Figure 5 -i. The whole data strictly proves high selectivity of oxide derived $\mathrm{Pb}$ for $\mathrm{HCO}_{2}^{-}$and great suppression of $\mathrm{H}_{2}$ generation. Kanan et al., used the same strategy for $\mathrm{Au}$ and obtained convincing results for ECR of $\mathrm{CO}_{2}$ by OD-Au. The reduction occured at very low overpotential $140 \mathrm{mV}$ and activity retained for almost 8 hours. In addition to this the author also suggested a reaction mechanism for polycrystalline as well as OD-Au, in the first case they considerd the formation of $\mathrm{CO}_{2}^{--}$as rate determining step while in the latter case formation of $\mathrm{CO}_{3}^{2-}$ from $\mathrm{HCO}_{3}^{-}$was assumed to be the rate determining step. For the sake of convinces the mechanism is summarized below. Recently Ager and lum had opened a new window regarding OD-M for ECR of $\mathrm{CO}_{2}$. According to them initially oxideds shows high degree of resistance to the reduction. Consequently this had a key role for the selective yielding of $\mathrm{C}_{2} / \mathrm{C}_{3} \mathrm{HCs}$ with a retention time up to five hours. They further conformed their statement by labeling oxygen of OD-Cu as ${ }^{18} \mathrm{O}$ [105]. This results further strengthen Kim et al., statement that he made in the light of his finding that metal-oxides (MO) which are normally used for OD-M, also have a sizeable contribution in the activity, durability and selectivity ECR of $\mathrm{CO}_{2}$ [106]. Kim study was contradictory to the previous findings but later on many researcher focus on that by conducting in situ analysis and find out valuable information, moreover they named it as residual oxide. These extraordinary performance may due to the active sites located on the grain boundaries produced at the time of conversion of $\mathrm{Cu}_{2} \mathrm{O}$ to OD-Cu [101].

\section{Metal-Oxide Interface and Grain Boundary (MOI \& GB)}

Metal oxide interfaces are of particular interest in material science and it plays a key role in the field of catalysis. Stacchiola et al., had explained the importance of MOI especially in catalysis, simply MOI are the junction area where metal and oxide meet [107]. 

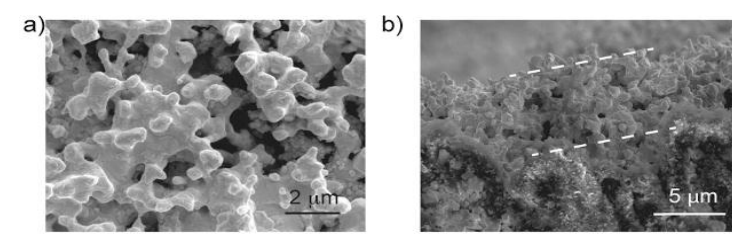

c)
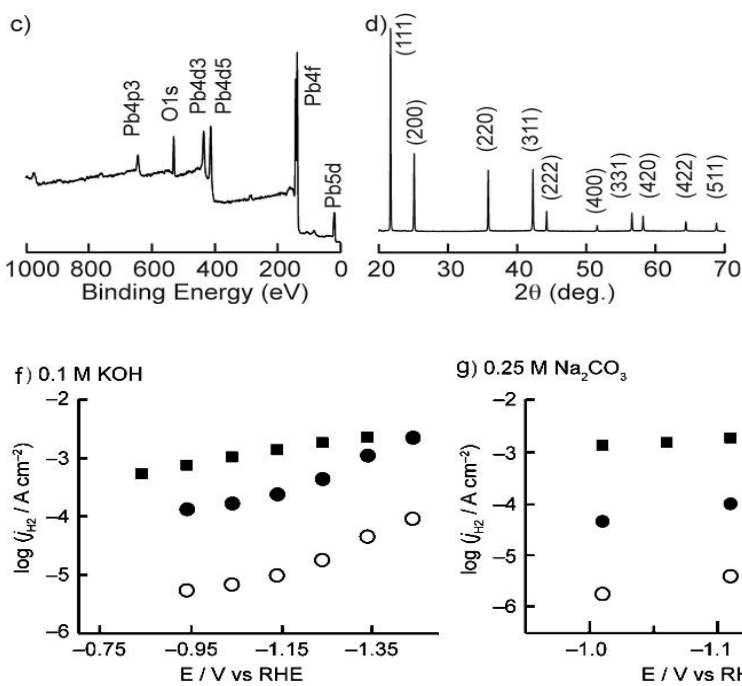

g) $0.25 \mathrm{M} \mathrm{Na}_{2} \mathrm{CO}_{3}$

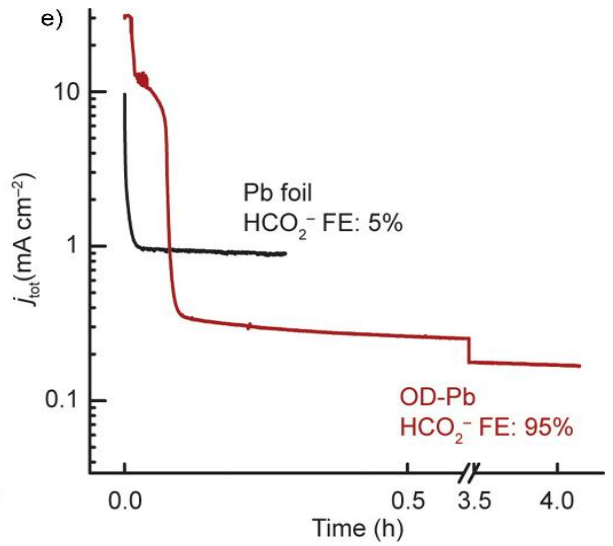

h) $0.325 \mathrm{M} \mathrm{H}_{2} \mathrm{SO}_{4} / \mathrm{NaHSO}_{4}$
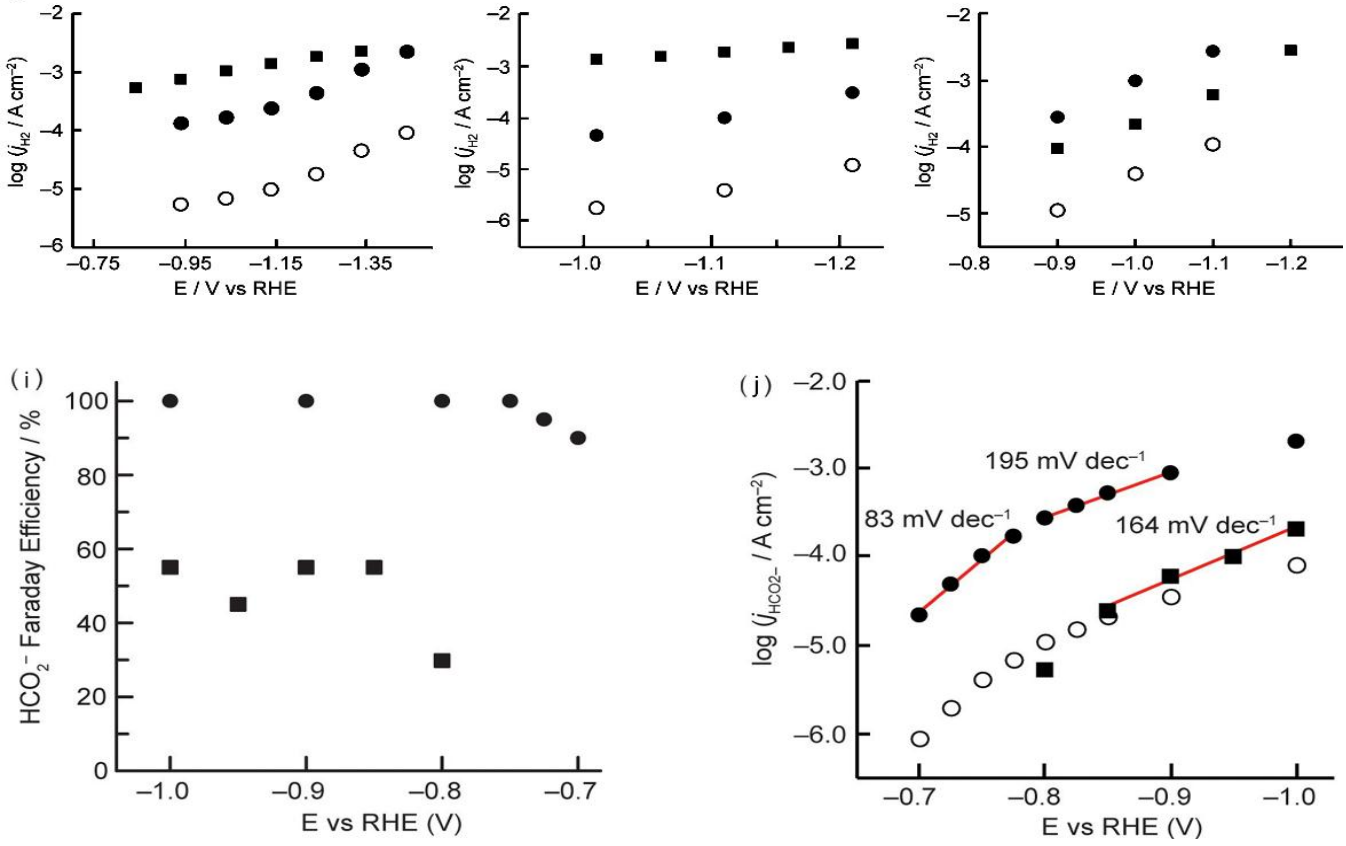

Figure 5. (a, b) Top-down \& cross-sectional SEM images. OD-Pb layer is represented by dashed lines. (c) XPS. (d) GIXD pattern (11.5 keV). (e) Comparative ECR of $\mathrm{CO}_{2}$ in $\mathrm{N}_{2}$-saturated $\mathrm{NaHCO}_{3}$ on $\mathrm{Pb}$ foil and $\mathrm{OD}-\mathrm{Pb}$. The large initial current for $\mathrm{OD}-\mathrm{Pb}$ is reduction of the $\mathrm{PbO}_{2}$ precursor. (f, $\mathrm{g} \& \mathrm{~h}$ ) Comparative HER on $\mathrm{Pb}$ foil and $\mathrm{OD}-\mathrm{Pb}$. Tafel plots for HER in alkaline, intermediate and acidic pH. (i) FE. (j) Tafel plot. Included are the geometric current densities for $\mathrm{Pb}$ foil ( $(\mathbf{)})$ and $\mathrm{OD}-\mathrm{Pb}(\bullet)$, and the current density for $\mathrm{OD}-\mathrm{Pb}$ corrected for roughness factor $(\mathrm{O})$ [104]. (Reproduced with permission from ref 104. Copyright 2014 ACS Catalysis.)

Proposed mechanisms for $\mathrm{CO}_{2}$ reduction on the polycrystalline $\mathrm{Au}$ and $\mathrm{OD}-\mathrm{Au}$.
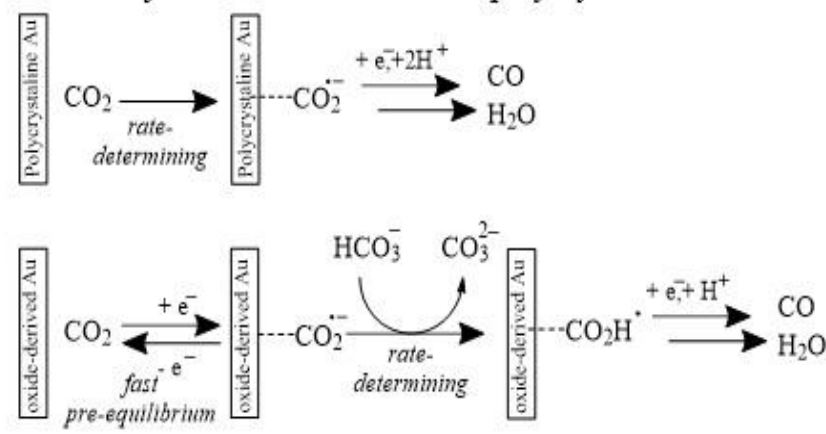
Metals and oxides are greatly differ from each other in materialistic properties. Such as metallic bonding in the metals is basically originates as a result of delocalization of electrons, while bonding in oxides is mostly ionic, so it's difficult to predict the bonding between oxides and metal, it may either covalent/ionic or metallic bonding, or a different interaction. On one hand the mismatch of materialistic properties across MOI is a great challenge for tuning materials to achieve a desired property, while on the other hand it makes MOI most exciting stuff in the materials science [108]. MOI application had successfully implemented in methanol synthesis [109], CO oxidation [110], and water-gas shift reaction [111]. Recently Bao et al. achieved a mile stone by throwing light on MOI with its particular implementation for $\mathrm{ECR} \mathrm{CO}_{2}$ [112].

They prepared $\mathrm{Au}-\mathrm{CeO}_{\mathrm{x}}$ and achieved remarkable activity and FE as compared to $\mathrm{Au}$. Only gaseous products were observed at the end electrocatalysis. The reactions take place during the whole process are given below.

$$
\begin{aligned}
& \mathrm{CO}_{2}(\mathrm{~g})+*+\mathrm{H}^{+}(\mathrm{aq})+\mathrm{e}^{-} \rightarrow{ }^{*} \mathrm{COOH} \\
& { }^{*} \mathrm{COOH}+\mathrm{H}^{+}(\mathrm{aq})+\mathrm{e}^{-} \rightarrow{ }^{*} \mathrm{CO}+\mathrm{H}_{2} \mathrm{O}(\mathrm{l}) \\
& { }^{*} \mathrm{CO} \rightarrow \mathrm{CO}(\mathrm{g})+*
\end{aligned}
$$

means that the intermediate $\left({ }^{*} \mathrm{COOH}\right)$ is stabilized by the Ce in its reduced form at interface. The MOI interaction, is mostly confinement effect in nanostructure supported on a substrate, provides the active sites and stabilize the intermediate.113 Additionally the hydroxyl group further enhances adsorption and activation which ultimately improves activity of the catalyst.

Computational studies also support the above given step wise mechanism. Free energy diagram is given in figure 6-b, which indicates that the formation of ${ }^{*} \mathrm{COOH}$ is the rate limiting step for both catalysts i.e., Au and
Au-Ce0x. Figure 6-b shows a significant difference in the free energy of both catalyst. Badar charges calculation reveals the fact that due to MOI formation and hydroxylation the oxidation state of Ce decreases. This means that the intermediate $\left({ }^{*} \mathrm{COOH}\right)$ is stabilized by the Ce in its reduced form at interface. The MOI interaction, is mostly confinement effect in nanostructure supported on a substrate, provides the active sites and stabilize the intermediate [113]. Additionally the hydroxyl group further enhances adsorption and activation which ultimately improves activity of the catalyst.

\section{Grain boundaries effect}

Grain boundaries (GB) are basically the juncture between adjacent grains or crystallites. It's a transition region comprised of some atoms which are not exactly aligned with either grain. Engineering GB improves the electrocatalytic ability of the NPs. Usually during the course of electrocatalysts NPs undergoes compositional and morphological variations [114]. GBs are considered as bulk defects but interestingly these defects have active sites or support active sites. During electrocatalysts on one hand it enhances the catalytic performance of the catalyst and on other hand stabilizes these defects or active sites on the defects. Simply these GBs are used as a stabilizer for active surfaces [101,115, 116]. As previously discussed that mostly edges play a main role in ECR of $\mathrm{CO}_{2}$ but for the first time Kanan et al., provided evidences and gives a quantitative relationship between surface coverage of certain structural characteristics and the surface-areanormalized activity for ECR of $\mathrm{CO}_{2}$ specially on $\mathrm{Au}$ NPs [117]. The same author have also investigated the reduction of $\mathrm{Au}$ and $\mathrm{Cu}$ oxide films resulted from ODM which is comprised of tightly interlinked GBs [50,61,101,118]. Kanana et al., prepared Au NPs by vapor deposition method and annealed at different temperature it was observed that the size of 
the NPs have a linear relation with annealing temperature and an inverse relation with

Figure 6. DFT calculations fo ECR of $\mathrm{CO}_{2}$ at 0 $\mathrm{V}$ vs $\mathrm{RHE}$ on $\mathrm{Au}(111)$ and $\mathrm{Ce}_{3} \mathrm{O}_{7} \mathrm{H}_{7} / \mathrm{Au}$ (111) surfaces. (a) Optimized structures for the main intermediates. (b) Calculated free energy diagram. "* $\mathrm{X}$ " indicates an adsorbed surface species [112]. (Reproduced with permission from ref 112. Copyright $2017 \mathrm{~J}$. Am. Chem. Soc.) surface area and GBs surface density.
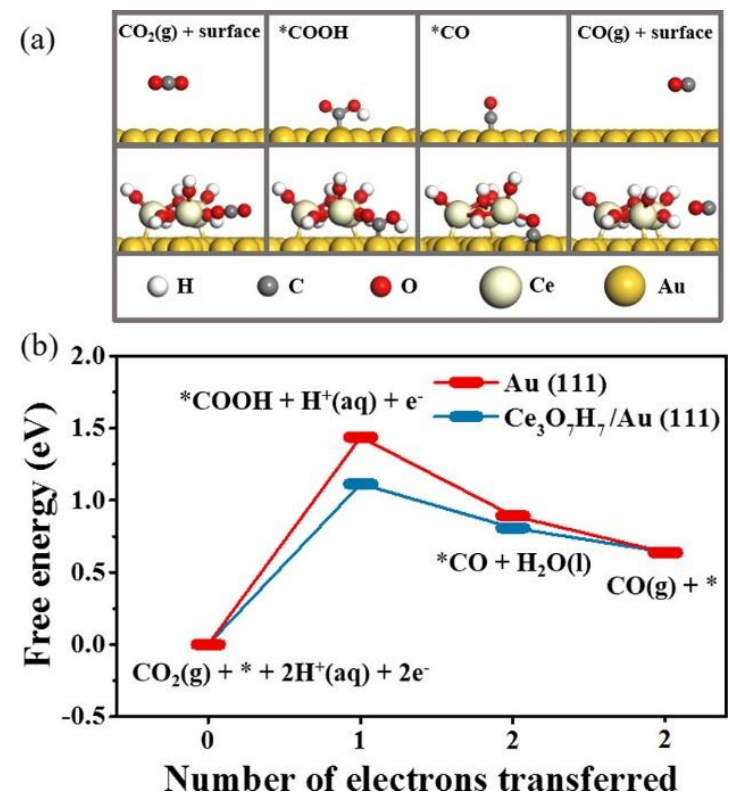

Figure 7. (a) Representative TEM before ECR, upper one Au NPs deposited on CNTs and lower one is after annealing at $200{ }^{\circ} \mathrm{C}$ (b) TEM after 12 hours ECR. Arrows indicates GBs (c) Time dependent total mass activity and $\mathrm{FE}$ for $\mathrm{CO}$ production for electrolysis at $-0.50 \mathrm{~V}$ vs $\mathrm{RHE}$ in $\mathrm{CO}_{2-}$ saturated $0.5 \mathrm{M} \mathrm{NaHCO}$. The current variations were due to the release of gas bubbles. (d) FE for CO production vs potential. (e) Mass activity for CO production on as-deposited $\mathrm{Au} / \mathrm{CNT}$ electrode [117]. (Reproduced with permission from ref 117 . Copyright $2015 \mathrm{~J}$. Am. Chem. Soc.)

The XPS profile confirms that no changes occurred on the Au NPs surface. Figure 7-d shows FE of four samples which indicates that annealing causes a regular decrease in FE of CO production which may be due to the regular increase in average size NPs or most probably due to decrease in GB surface density because both are interdependent on one another. The FE for as-deposited Au NPs on CNTs have tremendous FE along with long term retention activity as shown in Figure 7-c,
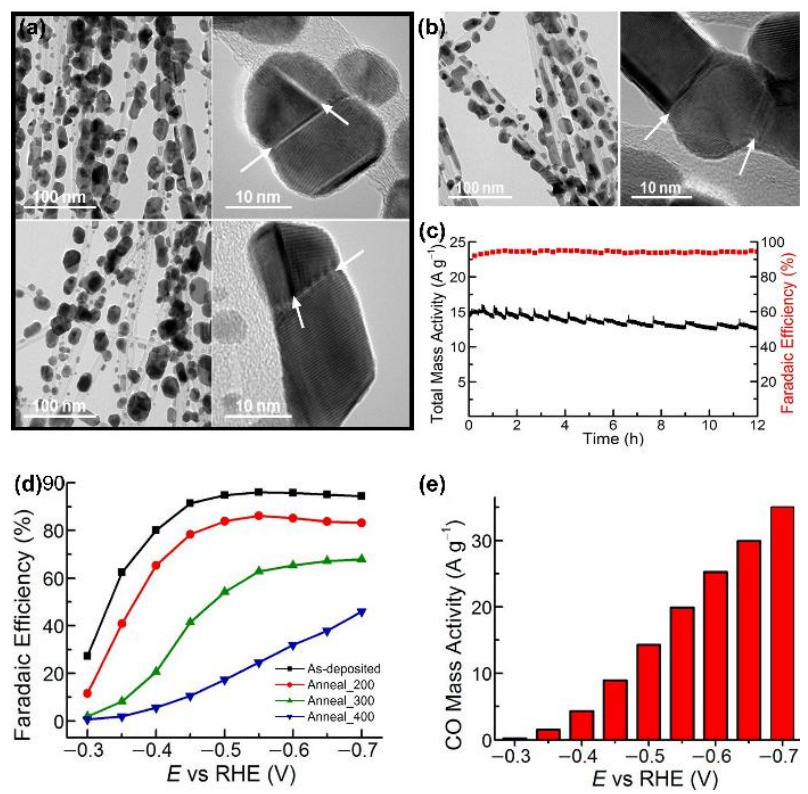

the total mass activity was observed $15 \mathrm{Ag}^{-1}$ which retained up to 12 hour (83\%). The highest mass activity was achieved at $-0.7 \mathrm{~V}$ vs RHE is $\sim 35 \mathrm{Ag}^{-1}$ for $\mathrm{CO}$ production.

\section{Metal alloy}

From the previous discussion it is clear that the activity as well as selectivity of the electrocatalyst (for ECR of $\mathrm{CO}_{2}$ ) are purely dependent on the binding power of 
intermediate. Alloys holds a paramount position in catalysis due to its unique physical, electronic and especially electrochemical properties. Alloys improve the catalytic ability of the metal electrocatalysts by tuning stability of the intermediate. Beside stability it also drop down the overpotential for ECR of $\mathrm{CO}_{2}$ [119]. Multicomponent system is far superior then its counter parts particularly in catalysis. Different research groups had prepared bimetallic alloys and achieved fascinating results, by breaking the linear correlation between the binding energies of $\mathrm{COOH}$ and $\mathrm{CO}$ on the electrode surface [120]. Watanabe et al., extensively studied $\mathrm{Cu}$ based alloys such as $\mathrm{Cu}-\mathrm{Zn}, \mathrm{Cu}-\mathrm{Sn}, \mathrm{Cu}-\mathrm{Cd}, \mathrm{Cu}-\mathrm{Pb}, \mathrm{Cu}-$ $\mathrm{Ni}$ and $\mathrm{Cu}-\mathrm{Ag}$. On the basis of his finding he stated that the alloys having distinct catalytic behaviour then their respective elements [121]. Lee et al., had successfully incorporated $\mathrm{Ag}$ in $\mathrm{Cu}_{2} \mathrm{O}-\mathrm{Cu}$ catalyst via electrochemical codeposition. Their findings indicates that the Ag incorporation booming ethanol selectivity and suppressing ethylene during ECR of $\mathrm{CO}_{2}$. Without Ag incorporation FE was $10.5 \%$ while after $\mathrm{Ag}$ incorporation it was recorded $34.15 \%$ and $20.1 \%$ for $\mathrm{Ag}-\mathrm{Cu}_{2} \mathrm{O}_{\mathrm{PB}}$ (phase blended) and $\mathrm{Ag}-\mathrm{Cu}_{2} \mathrm{O}_{\mathrm{PS}}$ (phase separated) respectively. This improved catalytic activity and selectivity was due to the suppression of the HER and enhancement of CO production [122]. Jin et al. had successfully prepared $\mathrm{Au}_{3} \mathrm{Cu}$ and reported that alloy having larger current density then its elemental atomic form. From product perspective Au produces $\mathrm{CO}$ while $\mathrm{Au}_{3} \mathrm{Cu}$ produces formate, ethylene and methane. The alloy formation, characterization and its yielding are given in Figure 8 [123].

Miyauchi et al., recently reported the synthesis of $\mathrm{Cu}-\mathrm{Zn}$ alloy by typical vacuum sealing approach, in which high energy $\mathrm{Zn}$ (vaporized form) was allowed to react with the $\mathrm{Cu}$ NPs or films. Then it was used for $\mathrm{CO}_{2}$ reduction, among different composition alloy $\mathrm{Cu}_{5} \mathrm{Zn}_{8}$ shows high ECR of $\mathrm{CO}_{2}$ was. Its FE was
$79 \%$ which is selectively Formic acid. This alloy shows an excellent stability for ECR of $\mathrm{CO}_{2}$ with a turn over number (TON) 1458.9 which is almost double then pure $\mathrm{Cu}$ 731.3. At this stage it's really important to discuss the speculated reaction pathway, although there are a number of research articles which had addressed this issue in detail [38,70,71,124]. Many scientist proposed that formic acid formation is dependent on the generation of $\mathrm{CO}_{2}^{--}$no matter its free or attached on the electrocatalyst surface $[37,125,126]$. As given in Figure 9, when the surface of the electrocatalyst had low binding power for $\mathrm{CO}_{2}^{--}$, just by transferring one electron carbon dioxide will be converted to $\mathrm{CO}_{2}^{--}$. The population of the radical will increases in the solution consequently carbon of the radical will easily undergoes hydrogenation, forming $\mathrm{HCOO}^{-}$. $\mathrm{Zn}$ surface having low binding potential for $\mathrm{CO}_{2}^{--}$, that is why the main product is $\mathrm{HCOO}^{-}$. However due to weak binding strength of $\mathrm{Zn}$ surface water splitting reaction arises as a competitive reaction for ECR of $\mathrm{CO}_{2}$ in aqueous media. Conseque- tly, it drop down Zn selectivity $[38,63]$. Takanabe et al. had selected $\mathrm{Cu}$-In alloy which is purely a non-noble electrocatalyst. $\mathrm{Cu}-\mathrm{In}$ was prepared in two steps, first OD-Cu was synthesized by thermal oxidation process in which $\mathrm{Cu}$ sheets were subjected to $773 \mathrm{~K}$ static air. This approach results nanowires on the substrate surface which not only increased the surface area but also increased the roughness factor by 140 times in comparison to pure $\mathrm{Cu}$ [127]. In the second step the in was incorporated on the surface of OD-Cu substrate from $\mathrm{InSO}_{4}$ solution in acidic media via electrodeposition. The roughness factor was further elevated by 2 -folds. Further the alloy was tested for ECR of $\mathrm{CO}_{2}$. Experimental results indicates that total current density was the same for both catalysts which means that rate of electron transfer are almost the same the only difference is in the selectivity. Before alloying 
catalyst show high $\mathrm{H}_{2}$ production selectivity while after alloying it was shifted towards $\mathrm{CO}$ and formic acid production, at $0.5 \mathrm{~V}$ vs RHE. The FE was reached to $90 \%$ which clearly indicates robust increase in the active sites after incorporation of In. The stability test indicates that $\mathrm{Cu}$-In alloy retain $85 \% \mathrm{FE}$ for $\mathrm{CO}$ production even after 7 hours. Comparative study of density-of-state (DOS) indicates that incorporation of In in OD-Cu don't change the electronic structure of the $\mathrm{Cu}$ even that the In ration in the alloy was up to $50 \%$, given in figure 10-a. these finding suggest that In play a major role in the local surface modification.

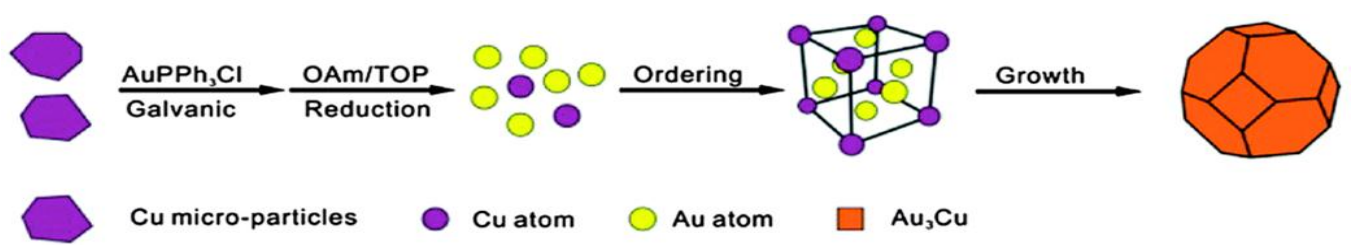

Schematic illustration of a growth pathway for the formation of $\mathrm{Au}_{3} \mathrm{Cu}$ truncated nanocubes.
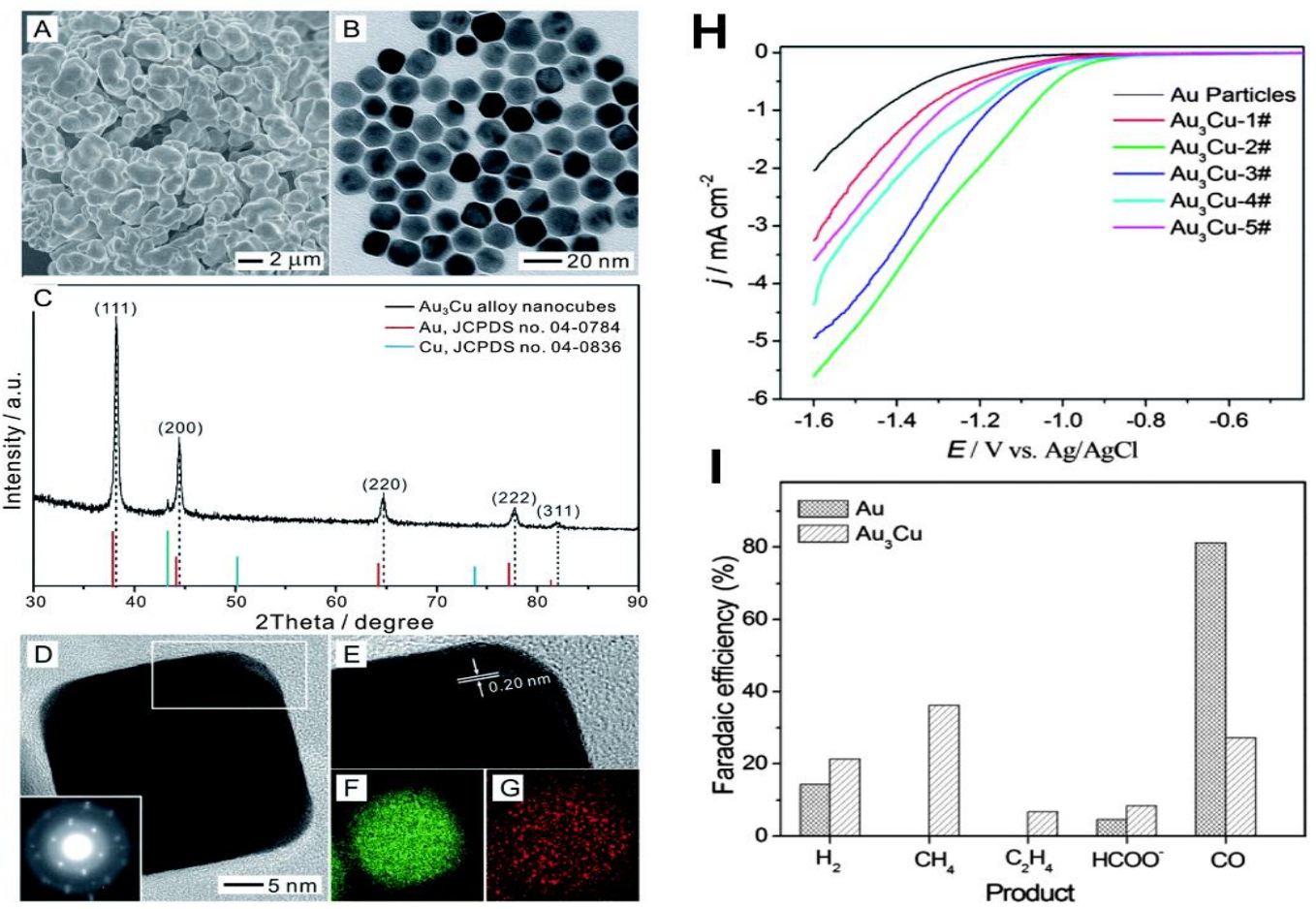

Figure 8. (A) SEM image of the $\mathrm{Cu}$ microparticles used as the $\mathrm{Cu}$ source; (B) TEM $\mathrm{Au}_{3} \mathrm{Cu}$ truncated nanocubes; $(\mathrm{C})$ the XRD pattern of $\mathrm{Au}_{3} \mathrm{Cu}$ truncated nanocubes, with the references for face-centered cubic (fcc) Au (JCPDS \# 04-0784) and fcc Cu (JCPDS \#04-0836) also shown for comparison; (D) a HRTEM image of an individual $\mathrm{Au}_{3} \mathrm{Cu}$ truncated nanocube; (E) a HRTEM image of the white rectangular area marked in (D); and EDX mapping images of the $\mathrm{Au}_{3} \mathrm{Cu}$ truncated nanocube: (F) Au, and (G) Cu (I) Electroreduction performances of the $\mathrm{Au}_{3} \mathrm{Cu} \mathrm{NCs}$ and the $\mathrm{Au}$ nanoparticles. The $\mathrm{Au}_{3} \mathrm{Cu}$ NCs prepared with different amounts of the Au precursor are given as $\mathrm{Au}_{3} \mathrm{Cu}-1 \#$ (10 mg), $\mathrm{Au}_{3} \mathrm{Cu}-2 \#$ (25 mg), $\mathrm{Au}_{3} \mathrm{Cu}-3 \#$ (50 mg), $\mathrm{Au}_{3} \mathrm{Cu}-4 \#$ (75 mg), and $\mathrm{Au}_{3} \mathrm{Cu}-5 \#(100 \mathrm{mg})$. (I) The comparison of the faradaic efficiency between $\mathrm{Au}_{3} \mathrm{Cu}-2 \#$ and the Au nanoparticles. Electrolyte: $0.1 \mathrm{M} \mathrm{KH}_{2} \mathrm{PO}_{4} / 0.1 \mathrm{M} \mathrm{K}_{2} \mathrm{HPO}_{4}, \mathrm{pH}=7$, electrolysis conditions: $E=$ $-1.6 \mathrm{~V}, t=3 \mathrm{~h}, T=25^{\circ} \mathrm{C}$ [123]. (Reproduced with permission from ref 123. Copyright 2014 The Royal Society of Chemistry) 
1. Free $\mathrm{CO}_{2}^{-}$radicals near the catalyst surface.

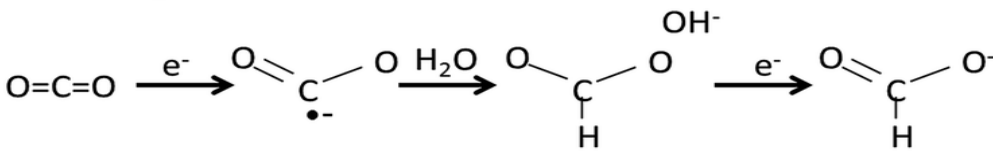

2. $\mathrm{CO}_{2}^{-}$radicals weakly adsorbed on the catalyst surface.

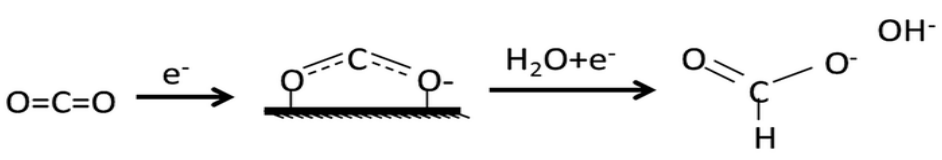

3. Strong $\mathrm{CO}_{2}$ radicals adsorption strength on the catalyst surface.

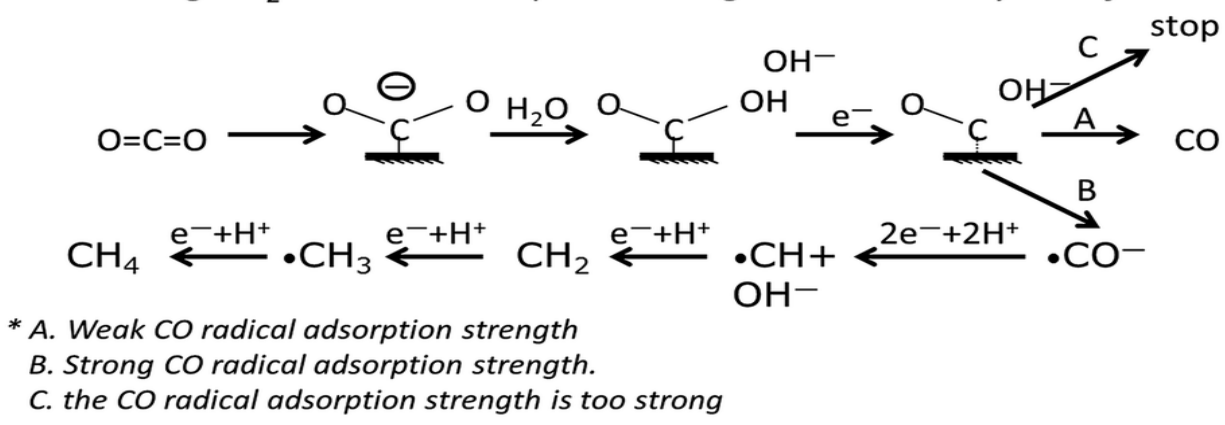

Figure 9. Proposed pathway for $\mathrm{CO}_{2}$ reduction [128]. (Reproduced with permission from ref 97. Copyright 2017. The Royal Society of Chemistry)

Figure 10. a) Density of states of $\mathrm{Cu}$ and of $\mathrm{Cu}_{11} \mathrm{In}_{9}$. The values for the d-band center are designated. b) Site preference of In replacing one $\mathrm{Cu}$ in $\mathrm{Cu}_{55}(\mathrm{lh})$ cluster. The energies relative to $\mathrm{Cu}_{55}-\mathrm{lh}$ are presented. In the case of $\mathrm{Cu}_{55}-\mathrm{Oh}$, the same site preference was obtained for In c) Side views of the three possible geometries of the (211) facet and top views of (100) and (111) facet of $\mathrm{Cu}$ with one In atom replacing a $\mathrm{Cu}$ atom. The energies relative to the most stable structure (left) is presented [129]. (Reproduced with permission from ref 129. Copyright 2015, Wiley-VCH)
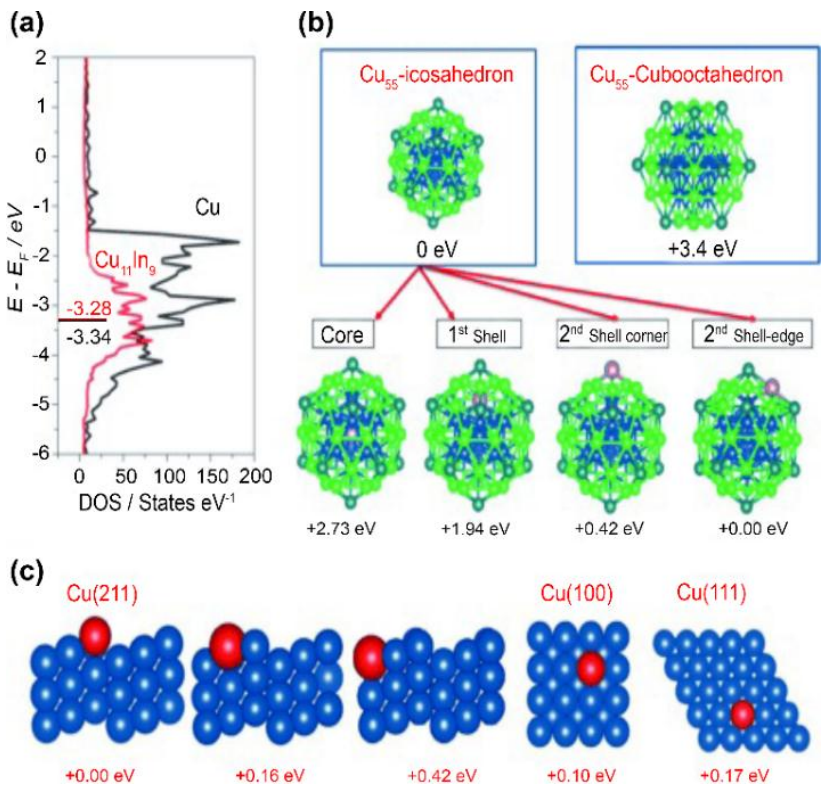

(b)

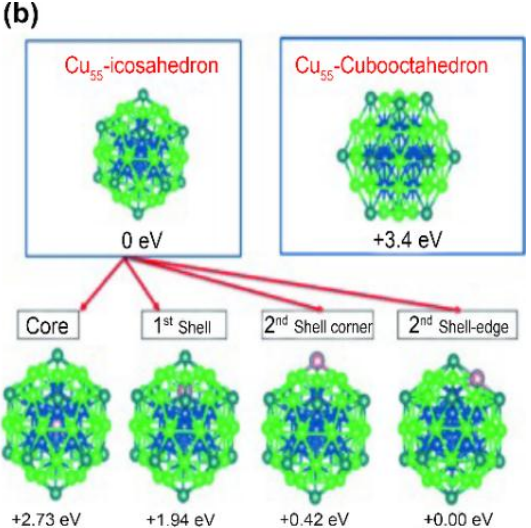

These finding suggest that in play a major role in the local surface modification. All possible geometries of $\mathrm{Cu}$-In alloys were thoroughly studied to conform surface modification. The effect of replacement single $\mathrm{Cu}$ atom by $\mathrm{In}$ and it its absorbance on $\mathrm{Cu}$ surface was studied in the modulated structure. $\mathrm{Cu}$ surface was considered to beperfect. This single atom replacement and absorption cannot represent real surface modification particularly when the in concentration is high but still the model gives significant information [130]. Figure 10-b represents first model. Indium atom prefer to 
replace edge $\mathrm{Cu}$ atom over corner atom. In the second model replacement of $\mathrm{Cu}$ atom on top of step at (211) is more preferable followed by (100) and (111) facet. Concluding that $\mathrm{Cu}-\mathrm{In}$ is one of the promising non-noble metal electrocatalyst that having FE 90\% for CO production with a retention of $80 \%$ activity till 7 hours [129].

\section{Metal free catalyst (MFC)}

Although a growing number of metal electrocatalysts have been used for ECR of $\mathrm{CO}_{2}$. Unfortunately metal catalysts preferentially like to off reduction of $\mathrm{H}_{2} \mathrm{O}$ to $\mathrm{H}_{2}$, while other catalysts such as $\mathrm{Pb}, \mathrm{Au}$ and $\mathrm{Ag}$ follow two electron path way for $\mathrm{CO}$ and HCOO $^{-}[131,132]$. The 2D materials, organometallics and CNTs, nitrogen doped graphene, and carbon fibers having only potential of CO production [133-137]. According to our information $\mathrm{Cu}$ or OD-Cu catalyst is the only catalyst among all screened electrocatalyst used for ECR of $\mathrm{CO}_{2}$ that have the ability of production of low carbon HCs and oxygenates with high FE via multiple step course of electron transfer $[61,138,139]$. Unfortunately $\mathrm{Cu}$ based catalyst suffer from high overpotential $-0.7 \mathrm{~V}$ and the overall current densities are usually below 50 $\mathrm{mA} \mathrm{cm}^{-2} \quad[61,87,131,140]$. The above discussion clearly give stress on the development of catalyst that have the multitask potential such as having high selectivity for ECR of $\mathrm{CO}_{2}$ to $\mathrm{HCs}$ particularly multi-carbon $\mathrm{HCs}$ and oxygenates. Entering to the subnano zone metals catalytic ability robust compared to its counterparts $[93,141,142]$. Beside this, the most convincing and exciting is the use of carbon nanostructure and further finding defects by doping heteroatoms results high performance for ECR of $\mathrm{CO}_{2}$ [135-137,143,144]. Ajayan et al. had prepared nitrogen doped carbon nanostructure and prepared an amazing metal free catalyst specially nitrogen doped graphene quantum dots (NGQDs) which having high current density for $\mathrm{ECR}$ of $\mathrm{CO}_{2}$ and low overpotential with multi-carbon $\mathrm{HCs}$ such as $\mathrm{C}_{2} \mathrm{H}_{5} \mathrm{OH}$ and $\mathrm{C}_{2} \mathrm{H}_{6}$ given in Figure 11. The NGQDs synthesized were of atomic size (Figure 11-a, b) and morphologically honey comb structure (inset Figure 10-b) revealing the retention of GO morphology, indistinguishability of heteroatom is due to the thinness compared to $\mathrm{Cu}$ supported grid. Figure 11-c indicates comparative Raman spectra, $\mathrm{N}$ doped samples have peculiar $\mathrm{D}$ and G bands at 1,350 and 1,589 $\mathrm{cm}^{-1}$ respectively. Simultaneously quenching of 2D band and high ratio of $\mathrm{I}_{\mathrm{D}} / \mathrm{I}_{\mathrm{G}}$ indicates increasing defects due to the incorporation of nitrogen. ECR of $\mathrm{CO}_{2}$ results indicates generation of single as well as multi-carbon $\mathrm{HCs}$ such as $\mathrm{C}_{2} \mathrm{H}_{4}$, $\mathrm{C}_{2} \mathrm{H}_{5} \mathrm{OH}, \mathrm{CH}_{4} n-\mathrm{C}_{3} \mathrm{H}_{7} \mathrm{OH}, \mathrm{CH}_{3} \mathrm{COO}^{-}$etc. given in figure 11-e. Tafel slope declined from 371 to

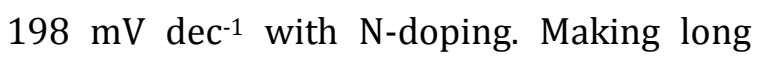
story short, NGQDs is a potential metal free catalyst with selective production of $\mathrm{C}_{2}-\mathrm{C}_{2}$ HCs and oxygenates as a result of ECR of $\mathrm{CO}_{2}$ [145]. Cai et al., had reported DFT study of Ndoped graphene (NDG) for ECR of $\mathrm{CO}_{2}$. They proved that $N$-doping alters the electronic arrangement of graphene and boosting formic acid and CO production with a low energy obstruction which is due to low overpotential $0.24 \mathrm{~V}$. It is suggested that NDG with pyrroliclike $\mathrm{N}$ is one of capable MFC for ECR of $\mathrm{CO}_{2}$ [146]. Sun et al., had experimentally proved that $\mathrm{N}$-doped mesoporous cylindrical carbon as a MFC for significant production of $\mathrm{C}_{2} \mathrm{H}_{5} \mathrm{OH}$ with FE $77 \%$ and selectivity $\sim 100 \%$ at $0.56 \mathrm{~V}$ vs RHE. The N-doping mainly favors dimerization of * $\mathrm{CO}$ which consequently generates $C_{2}$ HCs [147]. Dun et al., had recently published a valuable review on MFC in which they had beautifully described different carbon material such fullerene, single walled CNTs, multi-walled CNTs, graphene, nano-cones, nano-diamonds etc. and their electrocatalytic ability regarding products, current density, Tafel slope, FEs, identification of pathway and active sites 
[148].
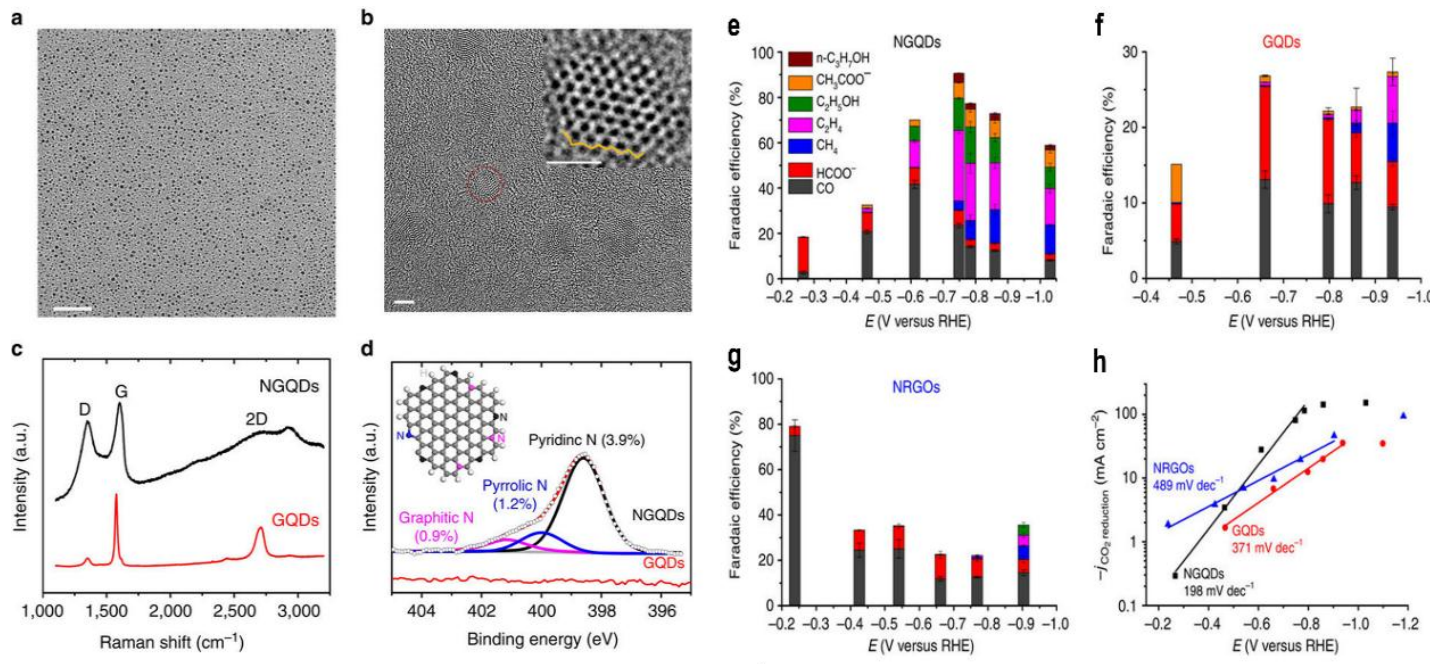

i

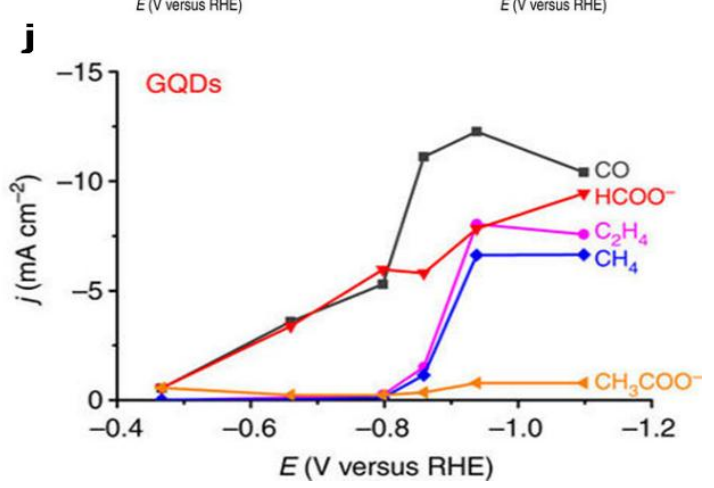

Figure 11. (a) Low-magnification TEM image of NGQDs. Scale bar, $50 \mathrm{~nm}$. (b) Highmagnification TEM image of NGQDs. Scale bar, $2 \mathrm{~nm}$. Inset shows a single NGQD containing zigzag edges as circled. The yellow line outlines the zigzag edge. Scale bar in inset, $1 \mathrm{~nm}$. (c) Raman spectrum of NGQDs as compared with that of pristine GQDs. (d) High-resolution $\mathrm{N} 1 \mathrm{~s}$ spectrum for NGQDs, deconvoluted into three sub-peaks representing pyridinic, pyrrolic and graphitic $\mathrm{N}$. The value in parentheses is the corresponding $\mathrm{N}$ atomic concentration calculated based on $\mathrm{N} /(\mathrm{N}+\mathrm{C})$. The inset is a schematic demonstrating zigzag edges and the $\mathrm{N}$-bonding configuration with respect to pyridinic (black), pyrrolic (blue) and graphitic (pink) N. In comparison, the $\mathrm{N} 1 \mathrm{~s}$ peak does not appear in GQDs sample. (e) FEs of $\mathrm{CO}, \mathrm{CH}_{4}, \mathrm{C}_{2} \mathrm{H}_{4}, \mathrm{HCOO}^{-}$, $\mathrm{C}_{2} \mathrm{H}_{5} \mathrm{OH}, \mathrm{CH}_{3} \mathrm{COO}^{-}$and $\mathrm{n}-\mathrm{CH}_{3}\left(\mathrm{CH}_{2}\right)_{2} \mathrm{OH}$ at various applied cathodic potential for NGQDs. (f) FE of $\mathrm{CO}_{2}$ reduction products for pristine GQDs. (g) Selectivity to $\mathrm{CO}_{2}$ reduction products for NRGOs. (h) Tafel plots of partial current density of $\mathrm{CO}_{2}$ reduction versus applied cathodic potential for three nanostructured carbon catalysts. The error bar represents the s.d. of three separate measurements for an electrode. (i) Partial current densities as a function of cathode potential using NGQDs as cathode (j) using GQDs as cathode catalyst for various products from electrochemical $\mathrm{CO}_{2}$ reduction [145]. (Reproduced with permission from ref 145 . Copyright 2016, Nature Publishing Group.)

\section{Conclusion and future perspective}

ECR of $\mathrm{CO}_{2}$ is an evergreen topic because: 1) atmospheric $\mathrm{CO}_{2}$ level can be controlled which is a serious threat to entire globe due to its dreadful consequences in the form of deforestation, global warming and ocean acidification. 2) The reduction products of $\mathrm{CO}_{2}$ having a key importance in energy sector and can play important role in overcoming energy 
problems. 3) This is an appropriate approach for preserving electrical energy in the form of high energy density (HED) chemicals.

Due to stable oxidation and linear structure of $\mathrm{CO}_{2}$, catalyst with high activity needed to cross the energy barrier and stabilize the reaction intermediates to obtain desired products. Some fundamental knowledge decorated with updated experimental as well as computational studies are briefly presented here which will hopefully give equal benefits to the beginners as will skilled researchers particularly electrochemists.

Although researcher contribute a lot to this hot area but still the current technologies need a lot of improvement to prove its versatility. The basic issues are low catalytic activity, high overpotential, catalyst unstability and low selectivity of desired product. Reaction intermediate stability is the key factor which should be properly handled. Here we summarizes some of the strategies for future work.

1. Plasma activation. Recently Cuenya et al., had achieved a mile stone in ECR of $\mathrm{CO}_{2}$ by plasma treatment of $\mathrm{Cu}$ nanocubes (100) tunable facets and achieved high activity for $\mathrm{C}_{2}-\mathrm{C}_{3}$ products, i.e., 45 and $22 \% \mathrm{FE}$ for ethylene and ethanol respectively, more interestingly the onset potential was quite low. They concluded that electrocatalytic activity can be regulated with plasma induction that can vary their morphology, ion content, defect density and roughness of the surface [149]. The same author had also studied the electrolyte effect on the plasma treated $\mathrm{Cu}$ foil particularly halide effect. Their finding indicates that halide not only favors nano-structuring but also lowering overpotential and selective $\mathrm{C}_{2}-$ $\mathrm{C}_{3}$ product formation with total $\mathrm{FE} \sim 65 \%$ [150].

2. Surface modification. Catalyst surface greatly influences the final product as well as catalytic activity. Comparatively rough surface having high performance then smooth ones because rough surface have larger ECSA, more edges, steps and defects and evenly high density of grain boundaries.

3. Downsizing. As a well-established fact that activity of catalyst is dependent on the active sites [151]. These active sites are linked with size, so entering from bulk to nano range the active sites and low coordinated sites increases. That's why they show high activities then bulk material [152]. Simply the catalytic ability order are as Bulk < nano < subnano < atomic, that's why recently the hot topic in the field of catalysis is single atom catalysis.

4. Metal free catalysis. As we briefly discussed MFC in section 3.5. MFC is a significant achievement in the ECR of $\mathrm{CO}_{2}$. But still need some improvements such as, I) synthetic process should be free of metal [153]. II) doping and surface defects, III) coupling traditional experimental practice with in situ analysis as well as computational to probe into the reaction mechanism., IV) suitable electrolytic system, as discussed earlier that electrolytic system had a great influence on the electrocatalysis, for instance by practicing ionic liquids (ILs) the selectivity and current density enhances because of strong sorption of carbon dioxide and declination in barrier for cleavage of $\mathrm{C}=0$ bond [154-159]. In addition to this competitive reaction for ECR of $\mathrm{CO}_{2}$ i.e., HER can be inhibited at low overpotential, however some ILs have some disadvantages, such as high cost, safety, low viscosity and environmental problems that need to properly addressed.

\section{Acknowledgment}

This work was supported by CAS-TWAS president's fellowship. 


\section{Conflicts of interest}

We declare no conflicts of interest.

\section{References}

[1]. Key World Energy Statistics, International Energy Agency 2017, 35. http://www.iea.org/statistics/

[2]. M.S. Dresselhaus, I.L. Thomas, Nature, 2001, 414, 332-337.

[3]. S. Chu, A. Majumdar, Nature, 2012, 488, 294-303.

[4]. J.G. Canadell, C. Le Quéré, M.R. Raupach, C. B. Field, E.T. Buitenhuis, P. Ciais, T.J. Conway, N.P. Gillett, R.A. Houghton, G. Marland, Proc. Natl. Acad. Sci. USA, 2007, 104, 18866 -18870. [5]. S.A. Marcott, J.D. Shakun, P.U. Clark, A. C. Mix, Science, 2013, 339, 1198-1201.

[6]. S.F. Tett, P.A. Stott, M.R. Allen, W.J. Ingram, J.F. Mitchell, Nature, 1999, 399, 569-572.

[7]. J.P. Smol, Nature, 2012, 483, S12- S15.

[8]. A.K. Tripati, C.D. Roberts, R.A. Eagle, Science, 2009, 326, 1394-1397.

[9]. O. Hoegh-Guldberg, P.J. Mumby, A.J. Hooten, R.S. Steneck, P. Greenfield, E. Gomez, C.D. Harvell, P.F. Sale, A.J. Edwards, K. Caldeira, N. Knowlton, Science, 2007, 318, 1737-1742.

[10]. D. Coumou, S. Rahmstorf, Nat. clim. change, 2012, 2, 491-496.

[11]. K.A. Giles, S.W. Laxon, A.L. Ridout, Geophys. Res. Lett., 2008, 35, L22502.

[12]. D.B. Lobell, W. Schlenker, J. CostaRoberts, Science, 2011, 333, 616-620.

[13]. G. Shaffer, S.M. Olsen, J.O.P. Pedersen, Nat. Geosci., 2009, 2, 105-109.

[14]. J.A. Church, N. J. White, Geophy. Res. Lett., 2006, 33, L01602.

[15]. C. D. Thomas, A. Cameron, R. E. Green, M. Bakkenes, L. J. Beaumont, Y. C. Collingham, B. F. Erasmus, M. F. De Siqueira, A. Grainger L. Hannah, Nature, 2004, 427(6970), 145-148. [16]. D.R. Feldman, W.D. Collins, P.J. Gero, M.S. Torn, E.J. Mlawer, T.R. Shippert, Nature, 2015, 519, 339-343.

[17]. M. E. Mann, Proc. Natl. Acad. Sci. USA.,
2009, 106, 4065-4066.

[18]. G.A. Olah, G.S. Prakash, A. Goeppert, J. Am. Chem. Soci., 2011, 133, 12881-12898.

[19]. S. Perathoner, G. Centi, Chemsuschem, 2014, 7, 1274-1282.

[20]. N.S. Lewis, D.G. Nocera, Proc. Natl. Acad. Sci., 2006, 103, 15729-15735.

[21]. D. Larcher, J.M. Tarascon, Nat. Chem., 2015, 7, 19-29.

[22]. M. Aresta, A. Dibenedetto, Dalton Trans., 2007, 28, 2975-2992.

[23]. K. Huang, C.L. Sun, Z.J. Shi, Chem. Soc. Rev., 2011, 40, 2435-2452.

[24]. M. Cokoja, C. Bruckmeier, B. Rieger, W.A. Herrmann F.E. Kühn, Ange. Chem. Int. Ed. Engl., 2011, 50, 8510-8537.

[25]. A.M. Appel, J.E. Bercaw, A.B. Bocarsly, H. Dobbek, D.L. DuBois, M. Dupuis, J.G. Ferry, E. Fujita, R. Hille, P.J.A. Kenis, C.A. Kerfeld, R.H. Morris, C.H.F. Peden, A.R. Portis, S.W. Ragsdale, T.B. Rauchfuss, J.N.H. Reek, L.C. Seefeldt, R.K. Thauer, G.L. Waldrop, Chem. Rev., 2013, 113, 6621-6658.

[26]. J. Albo, M. Alvarez-Guerra, P. Castano and A. Irabien, Green Chem., 2015, 17, 2304-2324. [27]. E.E. Benson, C.P. Kubiak, A.J. Sathrum, J.M. Smieja, Chem. Soc. Rev., 2009, 38, 89-99.

[28]. B. Kumar, M. Llorente, J. Froehlich, T. Dang, A. Sathrum, C.P. Kubiak, Ann. Rev. Phy. Chem., 2012, 63, 541-569.

[29]. C. Costentin, M. Robert, J.M. Saveant, Chem. Soc. Rev., 2013, 42, 2423-2436.

[30]. A. Taheri Najafabadi, Int. J. Ene. Res., 2013, 37, 485-499.

[31]. I. Ridjan, B.V. Mathiesen, D. Connolly, N. Duić, Energy, 2013, 57, 76.-84.

[32]. J. Schneider, H. Jia, J.T. Muckerman, E. Fujita, Chem. Soc. Rev., 2012, 41, 2036-2051.

[33]. J.M. Savéant, Chem. Rev., 2008, 108, 2348-2378.

[34]. M. Rakowski Dubois and D. L. Dubois, Acc. Chem. Res., 2009, 42, 1974-1982.

[35]. H. Yoshio, K. Katsuhei, M. Akira, S. Shin, Chem. Lett., 1986, 15, 897-898.

[36]. H. Yoshio, S. Shin, Bull. Chem. Soc. Jap., 1982, 55, 660-665. 
[37]. Y.I. Hori, Electrochemical CO2 reduction on metal electrodes. In Modern aspects of electrochemistry, Springer, New York, NY. 2008, pp. 89-189.

[38]. Y.J. Zhang, V. Sethuraman, R. Michalsky, A.A. Peterson, ACS Catal., 2014, 4, 3742-3748. [39]. M. Azuma, K. Hashimoto, M. Hiramoto, M. Watanabe, T. Sakata, J. Electrochem. Soc., 1990, 137, 1772-1778.

[40]. K. Hara, A. Kudo, T. Sakata, J. Electroanal. Chem., 1995, 391, 141-147.

[41]. D.D. Zhu, J.L. Liu, S.Z. Qiao, Adv. Mat., 2016, 28, 3423-3452.

[42]. X. Ma, Z. Li, L.E.K. Achenie, H. Xin, J. Phy. Chem. Lett., 2015, 6, 3528-3533.

[43]. A.S. Varela, N. Ranjbar Sahraie, J. Steinberg, W. Ju, H.S. Oh, P. Strasser, Ange. Chem. Int. Edi., 2015, 54, 10758-10762.

[44]. L. Shi, T. Wang, H. Zhang, K. Chang, J. Ye, Adv. Funct. Mater., 2015, 25, 5360-5367.

[45]. Y. Hori, K. Kikuchi, S. Suzuki, Chem. Lett., 1985, 14, 1695-1698.

[46]. Y. Hori, H. Wakebe, T. Tsukamoto, 0. Koga, Electrochimica Acta, 1994, 39, 18331839.

[47]. P. Hirunsit, W. Soodsawang, J. Limtrakul, J. Phy. Chem. C, 2015, 119, 8238-8942.

[48]. J. Rosen, G.S. Hutchings, Q. Lu, R.V. Forest, A. Moore, F. Jiao, ACS Catal., 2015, 5, 45864591.

[49]. D.R. Kauffman, J. Thakkar, R. Siva, C. Matranga, P.R. Ohodnicki, C. Zeng, R. Jin, ACS Appl. Mater. Interfaces, 2015, 7, 15626-15632. [50]. Y. Chen, C.W. Li, M.W. Kanan, J. Am. Chem. Soc., 2012, 134, 1986-1989.

[51]. K. Iizuka, T. Wato, Y. Miseki, K. Saito, A. Kudo, J. Am. Chem. Soc., 2011, 133, 2086320868.

[52]. C. Kim, H.S. Jeon, T. Eom, M.S. Jee, H. Kim, C.M. Friend, B.K. Min, Y.J. Hwang, J. Am. Chem. Soc., 2015, 137, 13844-13850.

[53]. G. Yin, M. Nishikawa, Y. Nosaka, N. Srinivasan, D. Atarashi, E. Sakai, M. Miyauchi, ACS Nano, 2015, 9, 2111-2119.

[54]. S. Anandan, M. Miyauchi, Electrochem., 2011, 79, 842-844.
[55]. O.A. Baturina, Q. Lu, M.A. Padilla, L. Xin, W. Li, A. Serov, K. Artyushkova, P. Atanassov, F. Xu, A. Epshteyn, T. Brintlinger, M. Schuette, G.E. Collins, ACS Catal., 2014, 4, 3682-3695.

[56]. R. Reske, M. Duca, M. Oezaslan, K.J.P. Schouten, M.T.M. Koper, P. Strasser, J. Phy. Chem. Lett., 2013, 4, 2410-2413.

[57]. X. Chang, T. Wang, P. Zhang, Y. Wei, J. Zhao, J. Gong, Angew. Chem., 2016, 128, 8986 $-8991$.

[58]. W. Kim, H. Frei, ACS Catalysis, 2015, 5, 5627-5737.

[59]. S. Shoji, G. Yin, M. Nishikawa, D. Atarashi, E. Sakai, M. Miyauchi, Chem. Phy. Lett., 2016, 658, 309-314.

[60]. R. Hinogami, S. Yotsuhashi, M. Deguchi, Y. Zenitani, H. Hashiba, Y. Yamada, ECS Electrochem. Lett., 2012, 1, H17.-H19.

[61]. C.W. Li, M.W. Kanan, J. Am. Chem. Soc., 2012, 134, 7231-7234.

[62]. Q. Kang, T. Wang, P. Li, L. Liu, K. Chang, M. Li, J. Ye, Angew. Chem., 2015, 127, 855-859. [63]. E. Baytok, T. Aksu, M.A. Karsli, H. Muruz, Turk. J. Vet. Anim. Sci., 2005, 29, 469-474.

[64]. I. Toyoshima, G.A. Somorjai, Catal. Rev., 1979, 19, 105-159.

[65]. J.P. Jones, G.K.S. Prakash, G.A. Olah, Isr. J. Chem., 2014, 54, 1451-1466.

[66]. E. Roduner, Chem. Soci. Rev., 2014, 43, 8226-8239.

[67]. D.C. Grenoble, M.M. Estadt, D.F. Ollis, J. Catal., 1981, 67, 90-102.

[68]. A.A. Peterson, J.K. Nørskov, J. Phys. Chem. Lett., 2012, 3, 251-258.

[69]. C. Shi, H.A. Hansen, A.C. Lausche, J.K. Norskov, Phys. Chem. Chem. Phys., 2014, 16, 4720-4727.

[70]. H.A. Hansen, J.B. Varley, A.A. Peterson, J.K. Nørskov, J. Phys. Chem. Lett., 2013, 4, 388392.

[71]. K.P. Kuhl, T. Hatsukade, E.R. Cave, D.N. Abram, J. Kibsgaard, T.F. Jaramillo, J. Am. Chem. Soc., 2014, 136, 14107-14113.

[72]. W. Zhu, Y.J. Zhang, H. Zhang, H. Lv, Q. Li, R. Michalsky, A.A. Peterson, S. Sun, J. Am. Chem. Soc., 2014, 136, 16132-16135. 
[73]. J.H. Koh, H.S. Jeon, M.S. Jee, E.B. Nursanto, H. Lee, Y.J. Hwang, B.K. Min, J. Phys. Chem. C, 2014, 119, 883-889.

[74]. H. Mistry, R. Reske, Z. Zeng, Z.J. Zhao, J. Greeley, P. Strasser, B.R. Cuenya, J. Am. Chem. Soc., 2014, 136, 16473-16476.

[75]. W. Zhu, R. Michalsky, O.N. Metin, H. Lv, S. Guo, C.J. Wright, X. Sun, A.A. Peterson, S. Sun, J. Am. Chem. Soc., 2013, 135, 16833-16836.

[76]. Q. Lu, J. Rosen, Y. Zhou, G. S. Hutchings, Y. C. Kimmel, J.G. Chen, F. Jiao, Nat. commun., 2014, 5, 3242.

[77]. J. Rosen, G.S. Hutchings, Q. Lu, S. Rivera, Y. Zhou, D.G. Vlachos, F. Jiao, ACS Catal, 2015, 5, 4586-4591.

[78]. A. Salehi-Khojin, H.R.M. Jhong, B.A. Rosen, W. Zhu, S. Ma, P.J. Kenis, R.I. Masel, J. Phys. Chem. C, 2013, 117, 1627-1632.

[79]. T. Hatsukade, K.P. Kuhl, E.R. Cave, D.N. Abram, T.F. Jaramillo, Phys. Chem. Chem. Phys., 2014, 16, 13814-13819.

[80]. J. Li, B. Li, H. Shao, W. Li, H. Lin, Catalysts, 2018, 8, 89.

[81]. R.W. Wagemans, J.H. van Lenthe, P.E. de Jongh, A.J. Van Dillen, K.P. de Jong, J. Am. Chem. Soc., 2005, 127, 16675-16680.

[82]. A.A. Peterson, L.C. Grabow, T.P. Brennan, B. Shong, C. Ooi, D.M. Wu, C. W. Li, A. Kushwaha, A.J. Medford, F. Mbuga, Top. Catal., 2012, 55, 1276-1282.

[83]. H. Qian, M. Zhu, Z. Wu, R. Jin, Acco. Chem. Res., 2012, 45, 1470-1479.

[84]. J. Kleis, J. Greeley, N. Romero, V. Morozov, H. Falsig, A.H. Larsen, J. Lu, J. J. Mortensen, M. Dułak, K.S. Thygesen, J.K. Nørskov, K.W. Jacobsen, Catal. Lett., 2011, 141, 1067-1071. [85]. S. Back, M.S. Yeom, Y. Jung, ACS Catal, 2015, 5, 5089-5096.

[86]. D. Gao, H. Zhou, J. Wang, S. Miao, F. Yang, G. Wang, J. Wang and X. Bao, J. Am. Chem. Soc., 2015, 137, 4288-4291.

[87]. R. Reske, H. Mistry, F. Behafarid, B. Roldan Cuenya, P. Strasser, J. Am. Chem. Soc., 2014, 136, 6978-6986.

[88]. G. Attard, C. Barnes, Oxford Chemistry Primers, 1998, 59. ISBN: 9780198556862
[89]. Y.C. Hsieh, S.D. Senanayake, Y. Zhang, W. Xu, D.E. Polyansky, ACS Catal., 2015, 5, 53495356.

[90]. S. Liu, H. Tao, L. Zeng, Q. Liu, Z. Xu, Q. Liu, J.L. Luo, J. Am. Chem. Soc., 2017, 139, 21602163.

[91]. D.H. Won, H. Shin, J. Koh, J. Chung, H.S. Lee, H. Kim, S.I. Woo, Angew. Chem. Int. Ed., 2016, 55, 9297-9300.

[92]. S. Back, M.S. Yeom, Y. Jung, J. Phy. Chem. C, 2018, 122, 4274-4280.

[93]. S. Gao, Y. Lin, X. Jiao, Y. Sun, Q. Luo, W. Zhang, D. Li, J. Yang, Y. Xie, Nature, 2016, 529, 68-71.

[94]. A. Verdaguer-Casadevall, C.W. Li, T.P. Johansson, S.B. Scott, J.T. McKeown, M. Kumar, I.E. Stephens, M.W. Kanan, I. Chorkendorff, J. Am. Chem. Soc., 2015, 137, 9808-9811.

[95]. A. Eilert, F. Cavalca, F.S. Roberts, J.R. Osterwalder, C. Liu, M. Favaro, E.J. Crumlin, H. Ogasawara, D. Friebel, L.G. Pettersson, J. Phys. Chem. Lett., 2016, 8, 285-290.

[96]. D. Ren, Y. Deng, A.D. Handoko, C.S. Chen, S. Malkhandi, B.S. Yeo, ACS Catal, 2015, 5, 2814-2821.

[97]. Y. Chen, M.W. Kanan, J. Am. Chem. Soc., 2012, 134, 1986-1989.

[98]. S. Zhang, P. Kang, T. J. Meyer, J. Am. Chem. Soc., 2014, 136, 1734-1737.

[99]. A. Dutta, A. Kuzume, M. Rahaman, S. Vesztergom, P. Broekmann, ACS Catalysis, 2015, 5, 7498-7502.

[100]. M. Ma, B.J. Trześniewski, J. Xie, W.A. Smith, Angew. Chem. Int. Ed., 2016, 55, 97489752.

[101]. C.W. Li, J. Ciston, M.W. Kanan, Nature, 2014, 508, 504-507.

[102]. C.J. Stalder, S. Chao, M.S. Wrighton, J. Am. Chem. Soc., 1984, 106, 3673-3675.

[103]. S. Ghasemi, H. Karami, M.F. Mousavi, M. Shamsipur, Electrochem. Commun., 2005, 7, 1257-1264.

[104]. C.H. Lee, M.W. Kanan, ACS Catal, 2014, 5, 465-469.

[105]. Y. Lum, J.W. Ager, Angew. Chem. Int. Ed., 2018, 57, 551-554. 
[106]. D. Kim, S. Lee, J.D. Ocon, B. Jeong, J.K. Lee, J. Lee, Phys. Chem. Chem. Phys., 2015, 17, 824-830.

[107]. K. Mudiyanselage, S.D. Senanayake, L. Feria, S. Kundu, A.E. Baber, J. Graciani, A.B. Vidal, S. Agnoli, J. Evans, R. Chang, Angew. Chem. Int. Ed., 2013, 52, 5101-5105.

[108]. F. Ernst, Mater. Sci. Eng., 1995, 14, $97-$ 156.

[109]. J. Graciani, K. Mudiyanselage, F. Xu, A.E. Baber, J. Evans, S.D. Senanayake, D.J. Stacchiola, P. Liu, J. Hrbek, J.F. Sanz, Science, 2014, 345, 546-550.

[110]. Q. Fu, W.X. Li, Y. Yao, H. Liu, H.Y. Su, D. Ma, X.K. Gu, L. Chen, Z. Wang, H. Zhang, B. Wang, X. Bao, Science, 2010, 328, 1141-1144.

[111]. J.A. Rodríguez, S. Ma, P. Liu, J. Hrbek, J. Evans, M. Perez, Science, 2007, 318, 17571760.

[112]. D. Gao, Y. Zhang, Z. Zhou, F. Cai, X. Zhao, W. Huang, Y. Li, J. Zhu, P. Liu, F. Yang, G. Wang, X. Bao, J. Am. Chem. Soc., 2017, 139, 56525655.

[113]. F. Yang, D. Deng, X. Pan, Q. Fu, X. Bao, National Sci. Rev., 2015, 2, 183-201.

[114]. K. Manthiram, Y. Surendranath, A.P. Alivisatos, J. Am. Chem. Soc., 2014, 136, 7237 7240 .

[115]. A.N. Gavrilov, E.R. Savinova, P.A. Simonov, V.I. Zaikovskii, S.V. Cherepanova, G.A. Tsirlina, V.N. Parmon, Phys Chem Chem Phys, 2007, 9, 5476-5489.

[116]. S. Wang, S.P. Jiang, T. White, J. Guo, X. Wang, J. Phys. Chem. C, 2009, 113, 1893518645.

[117]. X. Feng, K. Jiang, S. Fan, M.W. Kanan, J. Am. Chem. Soc., 2015, 137, 4606-4609.

[118]. X. Min, Y. Chen, M.W. Kanan, Phys. Chem. Chem. Phys., 2014, 16, 13601-13604.

[119]. Z. Xu, E. Lai, Y. Shao-Horn, K. HamadSchifferli, Chem. Commun., 2012, 48, 56265628.

[120]. H. Hansen, C. Shi, A. Lausche, A. Peterson, J. Nørskov, Phys. Chem. Chem. Phys., 2016, 18, 9194-9201.

[121]. M. Watanabe, M. Shibata, A. Kato, M.
Azuma, T. Sakata, J. Electrochem. Soc., 1991, 138, 3382-3389.

[122]. S. Lee, G. Park, J. Lee, ACS Catalysis, 2017, 7, 8594-8604.

[123]. W. Zhao, L. Yang, Y. Yin, M. Jin, J. Mater. Chem. A, 2014, 2, 902-906.

[124]. J. K. Nørskov, T. Bligaard, J. Rossmeisl, C.H. Christensen, Nature chem., 2009, 1, 3746.

[125]. R. Kortlever, J. Shen, K.J.P. Schouten, F. Calle-Vallejo, M.T. Koper, J. Phys. Chem. Lett., 2015, 6, 4073-4082.

[126]. R. Chaplin, A. Wragg, J. Appl. Electrochem., 2003, 33, 1107-1129.

[127]. A.T. Garcia-Esparza, K. Limkrailassiri, F. Leroy, S. Rasul, W. Yu, L. Lin, K. Takanabe, J. Mater. Chem. A, 2014, 2, 7389-7401.

[128]. G. Yin, H. Abe, R. Kodiyath, S. Ueda, N. Srinivasan, A. Yamaguchi, M. Miyauchi, J. Mater. Chem. A, 2017, 5, 12113-12119.

[129]. S. Rasul, D.H. Anjum, A. Jedidi, Y. Minenkov, L. Cavallo, K. Takanabe, Angew. Chem. Int. Ed., 2015, 54, 2146-2150.

[130]. H.K. Lim, H. Shin, W.A. Goddard, Y.J. Hwang, B.K. Min, H. Kim, J. Am. Chem. Soc., 2014, 136, 11355-11361.

[131]. Y. Hori, H. Wakebe, T. Tsukamoto, 0. Koga, Electrochim Acta, 1994, 39. 1833-1839. [132]. J. Qiao, Y. Liu, F. Hong, J. Zhang, Chem. Soc. Rev., 2014, 43, 631-675.

[133]. S. Lin, C.S. Diercks, Y.B. Zhang, N. Kornienko, E.M. Nichols, Y. Zhao, A.R. Paris, D. Kim, P. Yang, O.M. Yaghi, Science, 2015, 349. 1208-1213.

[134]. M. Asadi, B. Kumar, A. Behranginia, B. A. Rosen, A. Baskin, N. Repnin, D. Pisasale, P. Phillips, W. Zhu, R. Haasch, Nature Commun., 2014, 5, 4470.

[135]. J. Wu, R. M. Yadav, M. Liu, P.P. Sharma, C.S. Tiwary, L. Ma, X. Zou, X.D. Zhou, B.I. Yakobson, J. Lou, ACS Nano, 2015, 9, 53645371.

[136]. J. Wu, M. Liu, P.P. Sharma, R.M. Yadav, L. Ma, Y. Yang, X. Zou, X.D. Zhou, R. Vajtai, B.I. Yakobson, Nano letters, 2015, 16, 466-470.

[137]. B. Kumar, M. Asadi, D. Pisasale, S. Sinha- 
Ray, B.A. Rosen, R. Haasch, J. Abiade, A.L. Yarin, A. Salehi-Khojin, Nat. commun., 2013, 4, 2819.

[138]. S. Ma, M. Sadakiyo, R. Luo, M. Heima, M. Yamauchi, P.J. Kenis, J. Power Sources, 2016, 301, 219-228.

[139]. K.P. Kuhl, E.R. Cave, D.N. Abram, T.F. Jaramillo, Energy Environ. Sci., 2012, 5, 70507059.

[140]. Y. Hori, A. Murata, R. Takahashi, J. Chem. Soc., Faraday Trans. 1, 1989, 85, 2309-2326.

[141]. C. Liu, B. Yang, E. Tyo, S. Seifert, J. DeBartolo, B. von Issendorff, P. Zapol, S. Vajda, L.A. Curtiss, J. Am. Chem. Soc., 2015, 137, 86768679.

[142]. C. Liu, H. He, P. Zapol, L.A. Curtiss, Phys. Chem. Chem. Phys., 2014, 16, 26584-26599.

[143]. S. Zhang, P. Kang, S. Ubnoske, M.K. Brennaman, N. Song, R.L. House, J.T. Glass, T.J. Meyer, J. Am. Chem. Soc. 2014, 136, 78457848.

[144]. N. Sreekanth, M.A. Nazrulla, T.V. Vineesh, K. Sailaja, K.L. Phani, Chem. Commun., 2015, 51, 16061-16064.

[145]. J. Wu, S. Ma, J. Sun, J.I. Gold, C. Tiwary, B. Kim, L. Zhu, N. Chopra, I.N. Odeh, R. Vajtai, A.Z. Yu, R. Luo, J. Lou, G. Ding, P.J.A. Kenis, P. M. Ajayan, Nat. Commun., 2016, 7, 13869.

[146]. Y. Liu, J. Zhao, Q. Cai, Phys. Chem. Chem. Phys., 2016, 18, 5491-5498.

[147]. Y. Song, W. Chen, C. Zhao, S. Li, W. Wei, Y. Sun, Angew. Chem. Int. Ed., 2017, 56, 1084010844.

[148]. X. Duan, J. Xu, Z. Wei, J. Ma, S. Guo, S. Wang, H. Liu, S. Dou, Adv. Mater., 2017, 29, 1701784.

[149]. D. Gao, I. Zegkinoglou, N.J. Divins, F. Scholten, I. Sinev, P. Grosse, B. Roldan Cuenya, ACS Nano, 2017, 11, 4825-4831.

[150]. D. Gao, F. Scholten, B. Roldan Cuenya, ACS Catalysis, 2017, 7, 5112-5120.

[151]. M.S. Faber, S. Jin, Energy Environ. Sci., 2014, 7, 3519-3542.

[152]. Q. Lu, J. Rosen, F. Jiao, ChemCatChem, 2015, 7, 38-47.

[153]. Y. Li, W. Zhou, H. Wang, L. Xie, Y. Liang,
F. Wei, J.C. Idrobo, S.J. Pennycook, H. Dai, Nat. nanotechnol., 2012, 7, 394-400.

[154]. T. Kondo, S. Casolo, T. Suzuki, T. Shikano, M. Sakurai, Y. Harada, M. Saito, M. Oshima, M.I. Trioni, G.F. Tantardini, J. Nakamura, Phys. Rev. B, 2012, 86, 035436.

[155]. B. Li, X. Sun, D. Su, Phys. Chem. Chem. Phys., 2015, 17, 6691-6694.

[156]. X. Sun, X. Kang, Q. Zhu, J. Ma, G. Yang, Z. Liu, B. Han, Chem. Sci., 2016, 7, 2883-2887.

[157]. H. Liu, Y. Liu, J. Li, Phys. Chem. Chem. Phys., 2010, 12, 1685-1697.

[158]. B.A. Rosen, A. Salehi-Khojin, M.R. Thorson, W. Zhu, D.T. Whipple, P.J. Kenis, R.I. Masel, Science, 2011, 334, 643-634.

[159]. G.R. Zhang, B.J. Etzold, J. Energy Chem., 2016, 25, 199-207.

How to cite this manuscript: Fawad Ahmad, Carbon Dioxide Electrochemical Reduction over Metal and Metal Free Nanostructures: Recent Progress and Future Perspective, $A d v$. J. Chem. A, 2020, 3(1), 70-93. 